\title{
Study of parcels-based Land Use Planning in Urban areas dan Rural Areas (Case Study of Mantrijeron Sub-district, Yogyakarta City and Bambanglipuro Sub-district, Bantul Regency)
}

Hary L. Prabowo

Kementerian Agraria dan Tata Ruang/BPN, Kantor Pertanahan Kabupaten Bantul, Indonesia

\section{Article History:}

Received 13 December 2018

Received in revised form 5 June 2019

Accepted 11 June 2019

Available online 28 June 2019

\section{Keywords:}

Land Use Panning, Parcels Map

Corresponding Author:

Hary L. Prabowo

Email: bersihbersinar@yahoo.co.id

\begin{abstract}
The Land Use Planning (LUP-Neraca Penatagunaan Tanah/NPGT) is a balance between land availability and the needs of tenure, use and utilization of land according to the Regional Spatial Plan (RTRW) function area. LUP is arranged sectorally and regionally. Examples of sectoral LUP are rice field planning and plantation field planning. While regional LUP is arranged at a certain administrative level. So far LUP has been prepared based on zones/ regions that are adjusted to the RTRW functions area. The LUP at the sub-district administrative level began to be initiated and to be implemented after almost all of district/ city LUPs were implemented. Sub-district LUP was supported by the availability of the Subdistrict Spatial Detail Plan (RDTR) on a 1:5.000 scale which became a reference in the permittance of space utilization, so that the subdistrict LUP was arranged on the same scale. In this paper an assessment of sub-district LUP was made based on the Parcels Map (PBT) that available in the land office. PBT displays land parcels based on land ownership and land tenure. LUP is carried out in urban areas and rural areas. Location of urban areas in Mantrijeron Sub-District, Yogyakarta City, while rural areas in Bambanglipuro Sub-District.

The stages of sub-district LUP consist of : data collection/ inventory; processing and analysis of data; and compilation of results and discussion. The data collection/ inventory phase includes activities for preparing work maps and collecting primary data and supporting data. The processing and analysis stage includes data processing on sub-district LUP compilation with GIS application (ArcGIS) and LUP analysis. LUP analysis consists of : analysis of land use changes, analysis of land use suitability and analysis of land availability. The stage of result preparation and discussion includes the preparation of the result of the analysis, a comparison between two regions that were studied, conclusions and recommendations.

The result of the parcels-based sub-district LUP shows that land tenure and ownership information is very detailed; the information of land use and utilization in one parcel of land can consist of more than one type. In urban areas, the size of land parcels is relatively small with more varied types of land use and utilization than rural areas. As a note, that the coverage of parcels map in rural areas still needs to be improved because there are still empty areas.
\end{abstract}

(C) Author(s) 2019. This is an open access article under the Creative Commons Attribution-ShareAlike 4.0 International License (CC BY-SA 4.0).

\section{Pendahuluan}

Penyusunan Neraca Penatagunaan Tanah merupakan amanat Peraturan Pemerintah No. 16 Tahun 2004 tentang Penatagunaan Tanah Pasal 23 ayat (3) dan Undang -
Undang No. 26 Tahun 2007 tentang Penataan Ruang Pasal 33 ayat (2). Neraca Penatagunaan Tanah (NPGT) adalah perimbangan antara ketersediaan tanah dan kebutuhan penguasaan, penggunaan dan pemanfaatan tanah menurut fungsi kawasan Rencana Tata Ruang Wilayah (RTRW). 
Kajian dalam NPGT meliputi neraca perubahan penggunaan tanah, neraca kesesuaian penggunaan tanah terhadap RTRW, dan prioritas ketersediaan tanah. NPGT menyajikan informasi mengenai dinamika perubahan penggunaan tanah, kesesuaian penggunaan tanah terhadap rencana tata ruang, dan ketersediaan serta kebutuhan tanah sebagai arahan program strategis pertanahan (reforma agraria, pendaftaran tanah positif dan pengadaan tanah untuk kepentingan umum) dalam rangka menunjang pembangunan dan menjadi referensi dalam menerbitkan perizinan pemanfaatan ruang (ATR/BPN, 2018).

NPGT disusun secara sektoral dan regional. NPGT sektoral adalah penyusunan neraca penatagunaan tanah dengan kajian utama terhadap penggunaan dan pemanfaatan tertentu seperti sawah, perkebunan, perumahan, industri dan lain sebagainya. Contoh penyusunan NPGT sektoral adalah neraca sawah pada tahun 2011 dan neraca perkebunan tahun 2013 (ATR/BPN, 2016). NPGT regional adalah penyusunan neraca penatagunaan tanah dengan wilayah kajian berdasarkan wilayah administrasi tertentu. Contoh penyusunan NPGT regional adalah neraca penatagunaan tanah nasional, neraca penatagunaan tanah provinsi, neraca penatagunaan tanah kabupaten/kota dan neraca penatagunaan tanah kecamatan.

NPGT kecamatan mulai digagas untuk dilaksanakan setelah hampir seluruh neraca penatagunaan tanah kabupaten/kota dilaksanakan. Penyusunan neraca penatagunaan tanah kecamatan memberikan gambaran informasi penatagunaan tanah yang lebih detil sehingga dapat bermanfaat untuk pelaksanaan pembangunan pada umumnya maupun untuk meletakkan program-program strategis pertanahan khususnya.

Rencana pembangunan yang tertuang dalam Rencana Detail Tata Ruang (RDTR) Kecamatan skala 1 : 5.000 menjadi acuan dalam perijinan pemanfaatan ruang. RDTR adalah rencana pemanfaatan ruang kota yang disusun secara terinci untuk penyiapan perwujudan ruang dalam rangka pelaksanaan program-program pembangunan kota. Penyusunan RDTR didasarkan pada upaya untuk mewujudkan tujuan penataan ruang pada wilayah perencanaan tertentu/kecamatan, yang diterjemahkan dalam kebijakan dan strategi pengembangan struktur ruang dan pola ruang wilayah perencanaan tertentu. RDTR memuat rumusan kebijaksanaan pemanfaatan ruang wilayah yang disusun dan ditetapkan untuk menyiapkan perwuudan ruang Bagian Wilayah Perencanaan dalam rangka pelaksanaan program dan pengendalian pembangunan baik yang dilakukan oleh Pemerintah, swasta maupun masyarakat.

Ketersediaan RDTR tersebut perlu disusun neraca penatagunaan tanah kecamatan dengan skala yang sama. Penyusunan NPGT kecamatan dapat menjadi bahan evaluasi pemanfaatan ruang kecamatan. Selain itu dapat menjadi acuan dalam pelayanan administrasi pertanahan terutama dalam rangka penerbitan pertimbangan teknis pertanahan (ATR/BPN, 2018).

Dalam penyusunan NPGT kecamatan, Kementerian Agraria dan Tata Ruang telah menerbitkan Tata Cara Kerja
Penyusunan NPGT Kecamatan. Pengolahan dan analisis data spasial dalam penyusunan NPGT adalah berbasis zona/kawasan (zone based), baik itu NPGT sektoral maupun NPGT regional termasuk dalam penyusunan NPGT kecamatan.

Kegiatan pendaftaran tanah yang sangat masif melalui Pendaftaran Tanah Sistematik Lengkap (PTSL) dan didukung kegiatan Inventarisasi Pemilikan Penguasaan Penggunaan dan Pemanfaatan Tanah (IP4T) telah menghasilkan peta lengkap pada tingkat desa/kelurahan (Prabowo, 2016). Peta lengkap memuat seluruh atau sebagian besar bidang-bidang tanah pada wilayah desa/kelurahan. Peta bidang-bidang tanah tersebut tersedia di kantor-kantor pertanahan.

Dalam makalah ini, dilakukan pengkajian penyusunan NPGT kecamatan berbasis Peta Bidang Tanah (PBT) / parcel based di kawasan perkotaan dan kawasan perdesaan. Kawasan perkotaan yang dipilih adalah Kecamatan Mantrijeron Kota Yogyakarta. Untuk kawasan perdesaan dipilih Kecamatan Bambanglipuro Kabupaten Bantul. Kedua kecamatan tersebut merupakan lokasi kegiatan Penyusunan NPGT Kecamatan tahun anggaran 2017.

\section{Data dan Metodologi}

\subsection{Data dan Lokasi}

Data yang digunakan dalam penelitian ini terdari dari :

1. Data primer, terdiri dari :

a. Peta Administrasi

b. Data/informasi spasial penggunaan tanah

c. Data/informasi spasial RDTR

d. Data/informasi spasial penguasaan tanah

e. Peta Bidang Tanah

2. Data pendukung, terdiri dari :
a. Kecamatan dalam angka;
b. Monografi/potensi desa/kelurahan;
c. Data/informasi lainnya.

Lokasi penelitian adalah Kecamatan Mantrijeron Kota Yogyakarta dan Kecamatan Bambanglipuro Kabupaten Bantul.

\section{Kecamatan Mantrijeron}

Kecamatan Mantrijeron merupakan salah satu kecamatan di Kota Yogyakarta yang terletak di bagian barat daya Kota Yogyakarta. Kecamatan Mantrijeron terletak sekitar : $7^{\circ} 49^{\prime} 14,85^{\prime \prime}$ Lintang Selatan dan $110^{\circ} 21^{\prime} 40,95^{\prime \prime}$ Bujur Timur, dengan ketinggian 113 meter di atas permukaan laut

Kecamatan Mantrijeron terdiri dari 3 (tiga) kelurahan, yaitu Kelurahan Gedongkiwo, Kelurahan Suryodiningratan dan Kelurahan Mantrijeron. Adapun batas Kecamatan Mantrijeron sebelah utara adalah Kecamatan Kraton dan Kecamatan Ngampilan, sebelah timur adalah Kecamatan Kraton dan Kecamatan Mergangsan, sebelah selatan adalah Kabupaten Bantul dan sebelah barat adalah Kecamatan Wirobrajan dan Kabupaten Bantul. Luas wilayah Kecamatan Mantrijeron adalah 265,99 На (Yogyakarta, 2017). 
Penduduk Kecamatan Mantrijeron berdasar registrasi penduduk tahun 2017 sejumlah 35.298 jiwa dengan sex rasio 95,39 (Yogyakarta, 2018). Rincian luas wilayah dan jumlah penduduk Kecamatan Mantrijeron sebagai berikut :

Tabel 2.1. Luas Wilayah dan Jumlah Penduduk Kecamatan Mantrijeron

\begin{tabular}{clcc}
\hline No & Kelurahan & Luas (Ha) & $\begin{array}{c}\text { Jumlah } \\
\text { Penduduk }\end{array}$ \\
\hline 1 & Gedongkiwo & 90,78 & 13.993 \\
\hline 2 & Suryodiningratan & 88,31 & 11.105 \\
\hline 3 & Mantrijeron & 86,90 & 10.200 \\
\hline & Jumlah & 265,99 & 35.298 \\
\hline
\end{tabular}

Kecamatan Mantrijeron sudah memiliki RDTR yang termaktub dalam Peraturan Daerah Nomor 1 Tahun 2015 tentang Rencana Detail Tata Ruang dan Peraturan Zonasi Kota Yogyakarta Tahun 2015-2035.

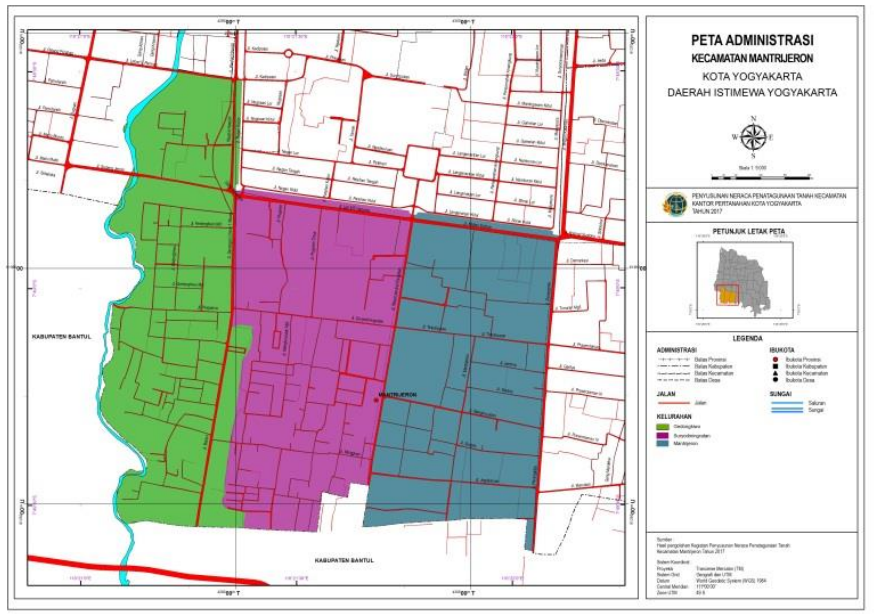

Gambar 2.1. Peta Administrasi Kecamatan Mantrijeron

\section{Kecamatan Bambanglipuro}

Kecamatan Bambanglipuro terletak di bagian tengah Kabupaten Bantul. Kecamatan Bambanglipuro secara geografis terletak antara $07^{\circ} 44^{\prime} 04^{\prime \prime}$ - 08 $00^{\circ} 27^{\prime \prime}$ Lintang Selatan dan $110^{\circ} 12^{\prime} 34^{\prime \prime}$ - 110³1'08" Bujur Timur, dan berada pada ketinggian $20 \mathrm{~m}$ dari permukaan laut. Kecamatan Bambaglipuro terdiri dari 3 (tiga) desa, yaitu Desa Sumbermulyo, Desa Mulyodadi dan Desa Sidomulyo. Adapun batas Kecamatan Bambanglipuro sebelah utara adalah Kecamatan Bantul, sebelah timur adalah Kecamatan Pleret dan Kecamatan Pundong, sebelah selatan adalah Kabupaten Kretek dan sebelah barat adalah Kecamatan Pandak. Luas wilayah Kecamatan Bambanglipuro adalah 2.275,37 Ha (Bantul, 2017).

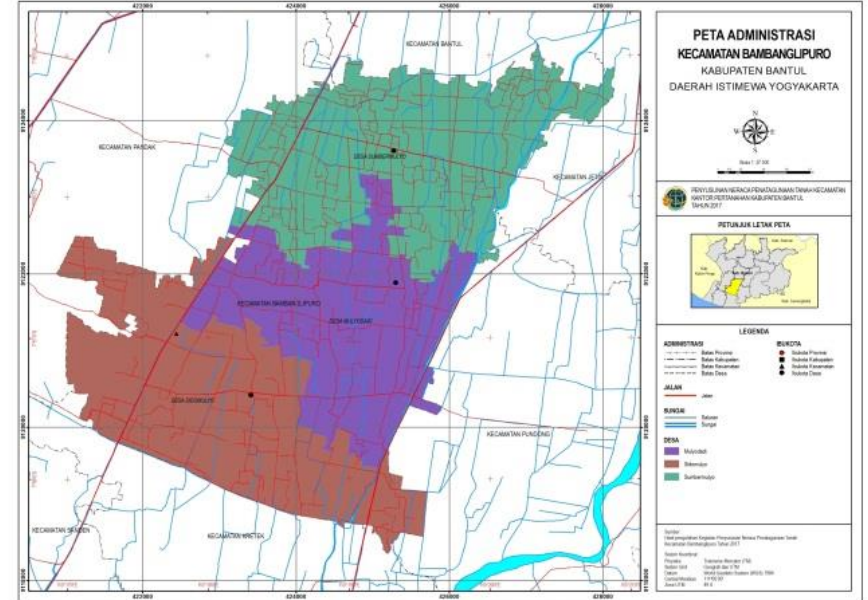

Gambar 2.2. Peta Administrasi Kecamatan Bambanglipuro

Penduduk Kecamatan Bambanglipuro berdasar registrasi penduduk tahun 2017 sejumlah 38.517 jiwa dengan sex rasio 97 (Bantul, 2018). Rincian luas wilayah dan jumlah penduduk Kecamatan Bambanglipuro sebagai berikut :

Tabel 2.2. Luas Wilayah dan Jumlah Penduduk Kecamatan Bambanglipuro

\begin{tabular}{clcc}
\hline No & Kelurahan & Luas (Ha) & $\begin{array}{c}\text { Jumlah } \\
\text { Penduduk }\end{array}$ \\
\hline 1 & Sumbermulyo & 821,642 & 14.848 \\
\hline 2 & Mulyodadi & 634,946 & 10.959 \\
\hline 3 & Sidomulyo & 818,778 & 12.710 \\
\hline & Jumlah & $2.275,367$ & 38.517 \\
\hline
\end{tabular}

Sumber : Hasil pengolahan dan BPS Kabupaten Bantul, 2018

Kecamatan Bambanglipuro belum memiliki RDTR yang tertuang dalam peraturan daerah, tetapi masih berupa dokumen kajian. Untuk itu, pengolahan dan analisis NPGT di Kecamatan Bambanglipuro mengacu kepada RTRW Kabupaten Bantul yang tertuang dalam Peraturan Daerah Kabupaten Bantul Nomor 4 Tahun 2011 tentang Rencana Tata Ruang Wilayah Kabupaten Bantul Tahun 20102030.rincian mengenai bahan utama dan pendukung yang digunakan dalam penelitian, serta lokasi penelitian.

\subsection{Metodologi}

Tahapan penyusunan NPGT kecamatan dalam makalah ini diadaptasi dari Tata Cara Kerja Penyusunan NPGT Tahun 2018. Tahapan diringkas hingga terdiri dari : pengumpulan/ inventarisasi data; pengolahan dan analisis data; dan penyusunan hasil dan pembahasan (ATR/BPN, 2018). 


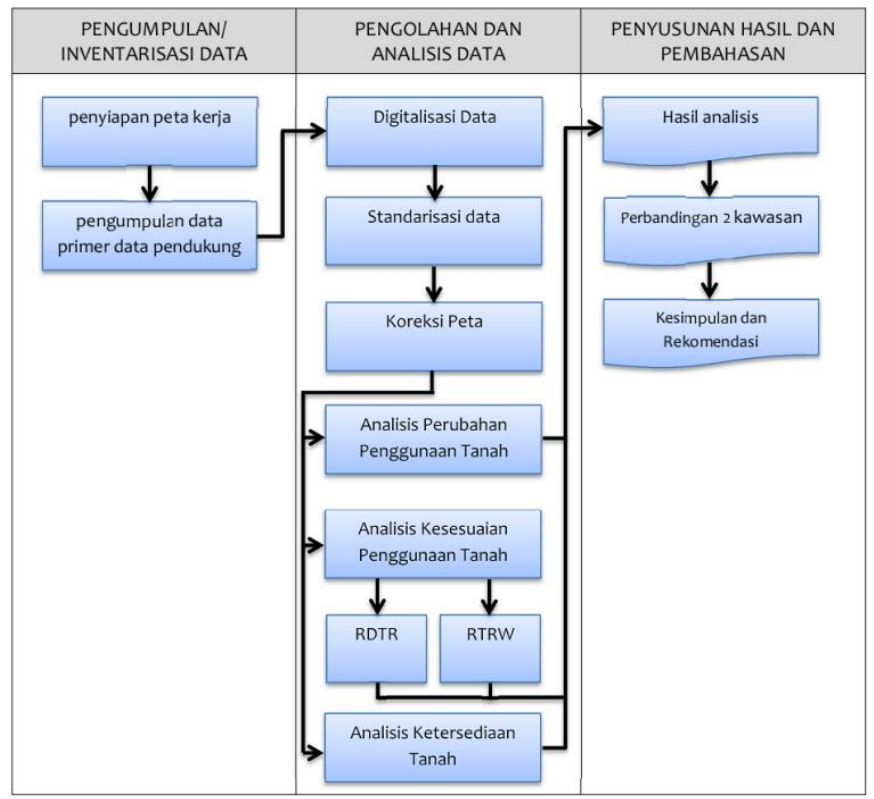

Gambar 2.3. Tahapan penyusunan NPGT

\section{Pengumpulan/inventarisasi data}

Pengumpulan/inventarisasi data meliputi kegiatan penyiapan peta kerja, pengumpulan data primer dan data pendukung.

1. Penyiapan peta kerja

Data/peta yang disiapkan untuk pembuatan peta kerja adalah:

a. Peta dasar yang bersumber dari Badan Informasi Geospasial (BIG)/lainnya;

b. Citra resolusi tinggi atau citra resolusi sangat tinggi (CSRT) dari LAPAN;

c. Peta bidang tanah terdaftar, peta lampiran pertimbangan teknis pertanahan dalam rangka ijin lokasi dari Kantor Pertanahan.

Tahapan pembuatan peta kerja:

a. Menyiapkan Peta Administrasi wilayah Kecamatan;

b. Interpretasi dan deliniasi citra di atas peta dasar (peta kerja untuk informasi penggunaan tanah);

c. Plotting bidang tanah terdaftar di atas peta dasar (peta kerja untuk informasi penguasaan/pemilikan tanah).

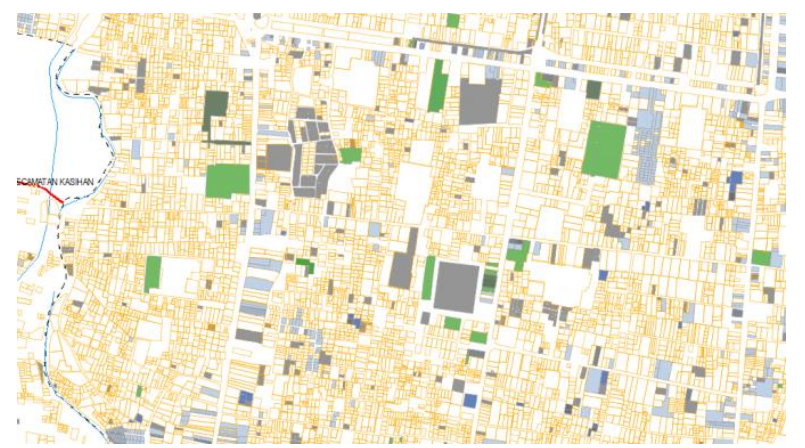

Gambar 2.4. Tampilan peta bidang tanah Kecamatan Mantrijeron

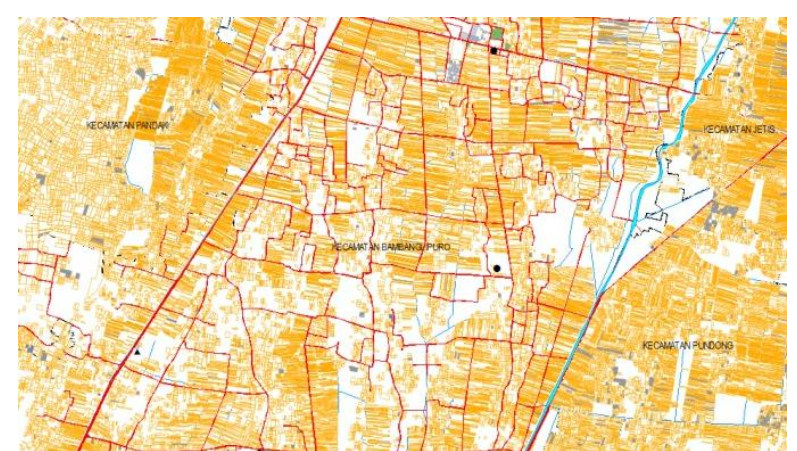

Gambar 2.5. Tampilan peta bidang tanah Kecamatan Bambanglipuro

2. Pengumpulan data primer dan data pendukung Data/informasi yang dikumpulkan dan diolah dalam kegiatan penyusunan neraca penatagunaan tanah kecamatan, meliputi :

a. Data Primer

1) Data/informasi spasial Penggunaan tanah Tahapan pendataan penggunaan tanah :

a) Pelaksanaan pendataan penggunaan tanah

Pendataan dilakukan untuk memperoleh informasi spasial penggunaan tanah. Teknik yang digunakan adalah melalui survey lapang dengan menjelajahi seluruh wilayah kecamatan dengan acuan peta kerja, apabila terdapat perbedaan penggunaan tanah di lapang, direkam menggunakan GPS sebagai bahan untuk updating peta penggunaan tanah.

b) Klasifikasi penggunaan tanah yang digunakan mengikuti Standarisasi Basisdata Spasial Penatagunaan Tanah tahun 2017, Direktorat Penatagunaan Tanah, Direktorat Jenderal Penataan Agraria Kementerian Agraria dan Tata Ruang/Badan Pertanahan Nasional.

2) Data/informasi

Penguasaan/pemilikan tanah

Tahapan pendataan penguasaan tanah :

a) Plotting bidang tanah yang sudah terdaftar dan hasil kegiatan IP4T pada peta kerja

b) Terhadap tanah yang belum terdaftar, data penguasaan tanah dapat diperoleh di Kelurahan/ desa dengan memanfaatkan peta $\mathrm{PBB}$, peta blok, peta rincikan, dll.

Pembaharuan data / informasi spasial penguasaan / pemilikan tanah dilaksanakan melalui pendataan yang direkam dengan GPS.

Klasifikasi penguasaan pemilikan tanah dan penyajian / pewarnaan peta mengikuti Standarisasi Basisdata Spasial Penatagunaan Tanah Tahun 2017 (Klasifikasi GUPT Kecamatan/Desa /Kelurahan). 
b. Data Pendukung, meliputi :

1) Peta RDTR /RTRW dalam bentuk hardcopy dan digital (.shp);

2) Kecamatan dalam angka;

3) Monografi/potensi desa/kelurahan.

\section{Pengolahan data}

Kegiatan pengolahan data penyusunan neraca penatagunaan tanah Kecamatan dilakukan dengan software spasial ArcGIS. Kegiatan ini meliputi digitalisasi hasil penjelajahan lapang (penggunaan dan penguasaan/pemilikan tanah) dan data pendukung, standarisasi data dan koreksi peta/data.

1. Digitalisasi data

Digitalisasi data dilakukan terhadap data :

a. Peta Penggunaan Tanah

Data penggunaan tanah hasil deliniasi dan penjelajahan lapang di buat dalam bentuk shapefile (.shp) selanjutnya diproses dengan menggunakan software spasial ArcGIS untuk membuat peta penggunaan tanah.

b. Peta Penguasaan/pemilikan Tanah

Data penguasaan tanah hasil ploting peta tanah terdaftar dan hasil IP4Tdan hasil inventarisasi penguasaan/pemilikan tanah di buat dalam bentuk shapefile (.shp) selanjutnya diproses dengan menggunakan software spasial ArcGIS untuk membuat peta penguasaan/pemilikan tanah.

c. Peta Administrasi Kecamatan

Penyesuaian batas administrasi desa/kelurahan hasil pengamatan lapang di buat dalam bentuk shapefile (.shp) selanjutnya diproses dengan menggunakan software spasial ArcGIS untuk membuat peta administrasi kecamatan.

2. Standarisasi data

Standarisasi data dilakukan untuk mempermudah dalam kegiatan analisis. Semua data harus sudah menggunakan system file yang sama yang sudah ditetapkan baik anotasi, penulisan atribut dan system penamaannya.

Standarisasi data dilakukan terhadap semua data yang digunakan dalam penyusunan neraca penatagunaan tanah yaitu peta administrasi, peta penggunaan tanah, peta penguasaan/ pemilikan tanah. Standarisasi kode coverage, data atribut (type feature, simbol atribut, nama atribut) dan struktur file mengikuti Standarisasi Basisdata Spasial Penatagunaan Tanah Tahun 2017.

3. Koreksi peta dan data

Koreksi peta dan data dilakukan terhadap :

a. Peta administrasi;

b. Peta penggunaan tanah;

c. Peta penguasaan/pemilikan tanah;

d. Peta RDTR/RTRW;

e. Peta kesesuaian penggunaan tanah terhadap RDTR/ RTRW;

f. Peta ketersediaan tanah.

Koreksi peta dimaksudkan untuk menyesuaikan/ menyeragamkan batas-batas spasial unsur-unsur alam dan buatan pada peta-peta tersebut. Unsur alam adalah sungai dan unsur buatan adalah jalan, gang, selokan dan blok bidang tanah. Koreksi peta dilakukan dengan cara menyesuaikan (editing) batas-batas unsur-unsur alam dan buatan dengan batas-batas spasial pada peta acuan. Peta acuan yang digunakan adalah peta bidang tanah yang memuat batas wilayah administrasi pemerintahan dan unsur-unsur alam dan buatan. Hasil koreksi peta adalah peta-peta yang memiliki batas-batas spasial unsur-unsur alam dan buatan yang seragam sehingga dalam proses analisis spasial berikutnya akan dihasilkan luasan poligonpoligon yang konsisten. Koreksi peta juga mengacu pada kaidah-kaidah kartografis dan standarisasi basisdata spasial penatagunaan tanah tahun 2017.

\section{Analisis data}

Analisis meliputi analisis perubahan penggunaan tanah, analisis kesesuaian penggunaan tanah terhadap RDTR/RTRW dan analisis ketersediaan tanah.

1. Analisis perubahan penggunaan tanah

Analisis perubahan penggunaan tanah dilakukan untuk mengetahui luas dan lokasi perubahan penggunaan tanah dalam kurun waktu tertentu (BPNRI, 2013).

Dalam analisis penggunaan tanah ini sebelumnya perlu diketahui terlebih dahulu kondisi penggunaan tanah pada tahun sebelum 2017 dan pada tahun 2017.

2. Analisis kesesuaian penggunaan tanah

Analisis kesesuaian penggunaan tanah dilakukan untuk mengetahui efektifitas pemanfaatan ruang. Kesesuaian penggunaan tanah terhadap tata ruang dibagi menjadi 2 (dua) yaitu analisis kesesuaian penggunaan tanah terhadap RDTR pada kecamatan yang sudah tersedia RDTR dan analisis kesesuaian penggunaan tanah terhadap RTRW pada kecamatan yang belum tersedia RDTR :

a. Kesesuaian penggunaan tanah dengan RDTR

Kesesuaian penggunaan tanah dengan RDTR adalah kesesuaian penggunaan tanah berdasarkan pola ruang yang dijabarkan dalam peraturan zonasi (zona dan sub zona) dalam RDTR. Zona dan subzona dalam RDTR terbagi menjadi zona/subzona kawasan lindung dan zona/subzona kawasan budidaya. Setiap zona dan subzona diatur kegiatan yang diizinkan, diizinkan terbatas, diizinkan bersyarat, dan tidak diizinkan. Matrik kesesuaian penggunaan tanah terhadap RDTR harus memperhatikan matrik ketentuan pemanfaatan ruang per sub-zonasi RDTR (diizinkan, diizinkan terbatas, diizinkan bersyarat dan tidak diizinkan). Dengan memperhatikan ketentuan pemanfaatan ruang dalam RDTR, maka klasifikasi kesesuaian penggunaan tanah terhadap peraturan zonasi dikelompokkan menjadi :

1) Sesuai, apabila penggunaan tanah saat ini sesuai dengan subzonasi pada RDTR (ketentuan pemanfaatan ruang di ijinkan, diizinkan terbatas dan diizinkan bersyarat) 
2) Tidak Sesuai, apabila penggunaan tanah saat ini tidak sesuai dengan subzonasi pada RDTR (ketentuan pemanfaatan ruang tidak diizinkan).

Tabel kesesuaian penggunaan tanah terhadap peraturan zonasi RDTR dibuat per zona kawasan dan persub zona kawasan. Untuk membuat tabel kesesuaian penggunaan tanah terhadap peraturan zonasi RDTR per zonasi kawasan, klasifikasi zonasi direklas menjadi :

1) Zona Lindung, adalah zonasi yang berfungsi lindung, termasuk hutan kota, jalur hijau, suaka alam margasatwa, budaya dan kawasan rawan bencana .

2) Zona Budidaya, adalah zonasi yang berfungsi untuk kegiatan budidaya seperti zona perumahan, zona perkantoran, zona perdagangan dan jasa atau komersial, zona pelayanan umum, zona pergudangan, dan sebagainya.

b. Kesesuaian penggunaaan tanah dengan RTRW kabupaten/kota

Kesesuaian penggunaan tanah dengan tata ruang kabupaten/kota yang dimaksud adalah kesesuaian penggunaan tanah terhadap pola ruang dalam Rencana Tata Ruang Wilayah Kabupaten/Kota. Dalam dokumen RTRW, terdapat arahan kegiatan/ pembangunan yang dapat digunakan sebagai referensi untuk analisis kesesuaian penggunaan tanah terhadap RTRW.

Kelas kesesuaian penggunaan tanah yang digunakan adalah :

1) Sesuai, apabila penggunaan tanah sesuai dengan arahan pola ruang.

2) Tidak sesuai, apabila penggunaan tanah tidak direkomendasikan dalam arahan pola ruang.

3. Analisis ketersediaan tanah

Sedangkan analisis ketersediaan tanah dilakukan untuk memberikan informasi mengenai lokasi yang dapat digunakan untuk kegiatan pengembangan budidaya berdasarkan kesesuaian penggunaan tanah terhadap RDTR/RTRW dan penguasaan/pemilikan tanah. Ketersediaan tanah disini dilihat dari aspek RDTR/RTRW, penggunaan tanah dan status penguasaan/pemilikan Tanah (ATR/BPN, 2018).

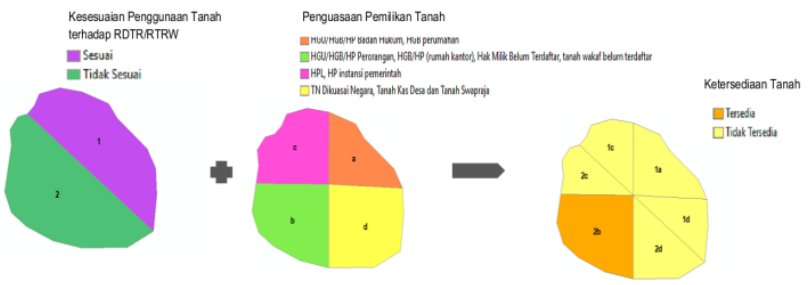

Gambar 6. Bagan analisis ketersediaan tanah
Analisis ketersediaan tanah dilakukan dengan overlay hasil analisis kesesuaian penggunaan tanah terhadap RDTR/RTRW, peta administrasi, dan peta penguasaan/pemilikan tanah. Ketersediaan tanah dikelompokkan menjadi 2 yaitu tersedia dan tidak tersedia.

1. Tersedia, jika penggunaan tanahnya tidak sesuai dengan RDTR/RTRW dan status penguasaan kepemilikan tanahnya selain HGU/HGB/HP Badan Hukum, HGB perumahan, HPL, HP instansi pemerintah, HGB/HP (rumah kantor) Badan Hukum, tanah wakaf terdaftar, TN Dikuasai Negara, Tanah Kas Desa dan Tanah Swapraja.

2. Tidak tersedia, jika penggunaan tanahnya sesuai dengan RDTR/RTRW dan/atau status penguasaan/ kepemilikan tanahnya merupakan HGU/HGB/HP Badan Hukum, HGB perumahan, HPL, HP instansi pemerintah, HGB/HP (rumah kantor) Badan Hukum, tanah wakaf terdaftar, TN Dikuasai Negara, Tanah Kas Desa dan Tanah Swapraja.

\section{Hasil dan Pembahasan}

Hasil dari setiap tahapan penyusunan NGPT adalah sebagai berikut.

\subsection{Pengumpulan/inventarisasi data}

Tahap pengumpulan/inventarisasi data terdiri dari penyiapan peta kerja dan pengumpulan data primer dan data pendukung.

\section{Penyiapan peta kerja}

Peta kerja dihasilkan dari overlay peta administrasi dan peta bidang tanah terdaftar terhadap peta dasar dari BIG. Peta bidang tanah diperoleh dari Aplikasi Komputerisasi Kantor Pertanahan (KKP). Peta dasar dari BIG berupa peta citra tegak resolusi tinggi. Peta kerja dibuat untuk setiap kelurahan/desa pada kertas ukuran A1. Skala pada peta kerja menyesuaikan luas wilayah kelurahan/desa.

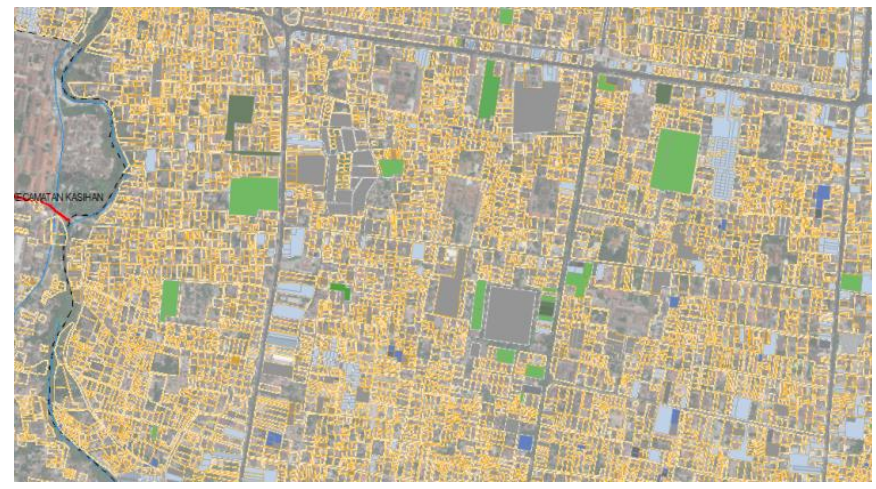

Gambar 3.1. Tampilan peta kerja wilayah Kecamatan Mantrijeron 


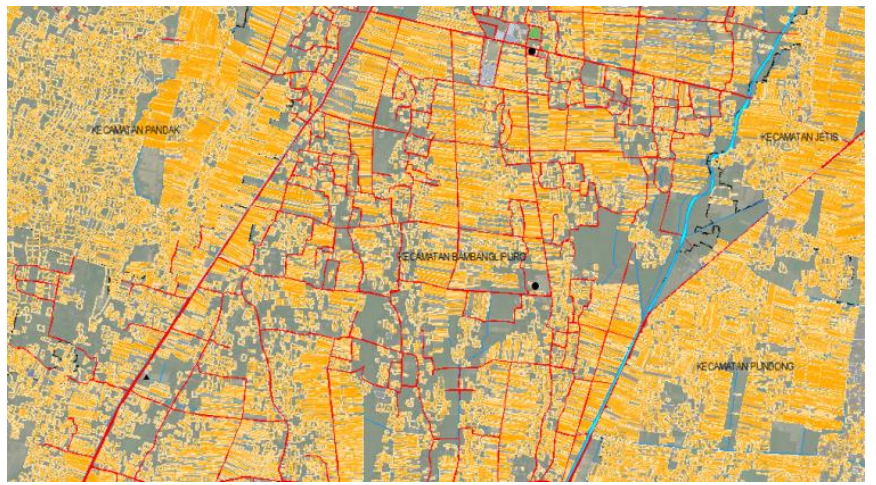

Gambar 3.2. Tampilan peta kerja wilayah Kecamatan Bambanglipuro

\section{Pengumpulan data primer dan data pendukung}

Data/informasi primer yang dikumpulkan dan diolah dalam kegiatan penyusunan NPGT kecamatan adalah penggunaan tanah dan penguasaan/pemilikan tanah.

Data penggunaan tanah diperoleh dari pendataan lapang melalui survey lapang dengan menjelajahi seluruh wilayah kecamatan dengan acuan peta kerja. Perubahan/perbedaan penggunaan tanah di lapang, direkam menggunakan GPS dan didokumentasikan. Data koordinat GPS sebagai bahan untuk updating peta penggunaan tanah.

Data penguasaan/pemilikan tanah berasal dari plotting bidang tanah yang sudah terdaftar dan hasil kegiatan IP4T pada peta kerja. Untuk tanah yang belum terdaftar, data penguasaan tanah diperoleh di desa dengan memanfaatkan peta PBB dan peta blok/persil. Pembaharuan data/informasi spasial penguasaan/pemilikan tanah juga dilaksanakan melalui pendataan yang direkam dengan GPS.

Wilayah Kecamatan Mantrijeron sudah terpetakan lebih dari 95\%, sementara wilayah Kecamatan Bambanglipuro diperkirakan sudah terpetakan lebih dari 80\%. Hal ini diketahui dari area kosong pada peta bidang tanah di Kecamatan Bambanglipuro.

\subsection{Pengolahan dan analisis data}

Tahap pengolahan dan analisis data penyusunan NPGT kecamatan dilakukan dengan software spasial ArcGIS.

\section{Digitalisasi data}

Kegiatan digitalisasi dilakukan terhadap data penggunaan tanah, penguasaan/pemilikan tanah dan batas administrasi. Hasil updating dan digitalisasi data penggunaan tanah ditampilkan sebagai Peta Penggunaan Tanah dan hasil updating penggunaan tanah ditampilkan sebagai Peta Penguasaan Tanah, sebagaimana ditampilkan pada Gambar 3.3 s.d. Gambar 3.6.

\section{Standarisasi data}

Standarisasi data dilakukan untuk mempermudah dalam kegiatan analisis. Semua data harus sudah menggunakan system file yang sama yang sudah ditetapkan baik anotasi, penulisan atribut dan system penamaannya.
Standarisasi data dilakukan terhadap semua data yang digunakan dalam penyusunan neraca penatagunaan tanah yaitu peta administrasi, peta penggunaan tanah, peta penguasaan/ pemilikan tanah.

Dalam buku panduan Standardisasi Basisdata Spasial Penatagunaan Tanah, skala kedetilan untuk klasifikasi jenis penggunaan tanah dibedakan antara wilayah perdesaan (rural) dan wilayah perkotaan (urban), sementara skala kedetilan untuk klasifikasi jenis penguasaan tanah dibedakan berdasarkan tingkat wilayah administrasi.

Skala kedetilan klasifikasi jenis penggunaan tanah di wilayah perdesaan dikelaskan/ dikelompokkan dalam skala : 1:100.000,1:50.000, 1:25.000/12.500 dan wilayah perkotaan dikelompokkan dalam skala : 1:25.000, 1:10.000 dan 1:5.000/ 2.500. Sementara untuk skala kedetilan klasifikasi jenis penguasaan tanah dibedakan/dikelompokkan dalam 3 wilayah administrasi yaitu : nasional, provinsi dan pulau; kabupaten/kota; dan kecamatan dan kelurahan/desa (ATR/BPN, 2017).

\section{Koreksi peta dan data}

Koreksi peta dan data dilakukan terhadap : peta administrasi; peta penggunaan tanah lama dan baru; peta penguasaan/pemilikan tanah; dan peta RDTR/RTRW. Koreksi juga dilakukan terhadap peta-peta hasil analisis, yaitu : peta perubahan penggunaan tanah; peta kesesuaian penggunaan tanah terhadap RDTR/ RTRW; dan peta ketersediaan tanah.

Koreksi dilakukan dengan mengacu peta bidang tanah dan membandingkan hasil pengolahan terhadap hasil pendataan lapangan serta kaidah-kaidah kartografis dan standarisasi basisdata spasial penatagunaan tanah tahun 2017.

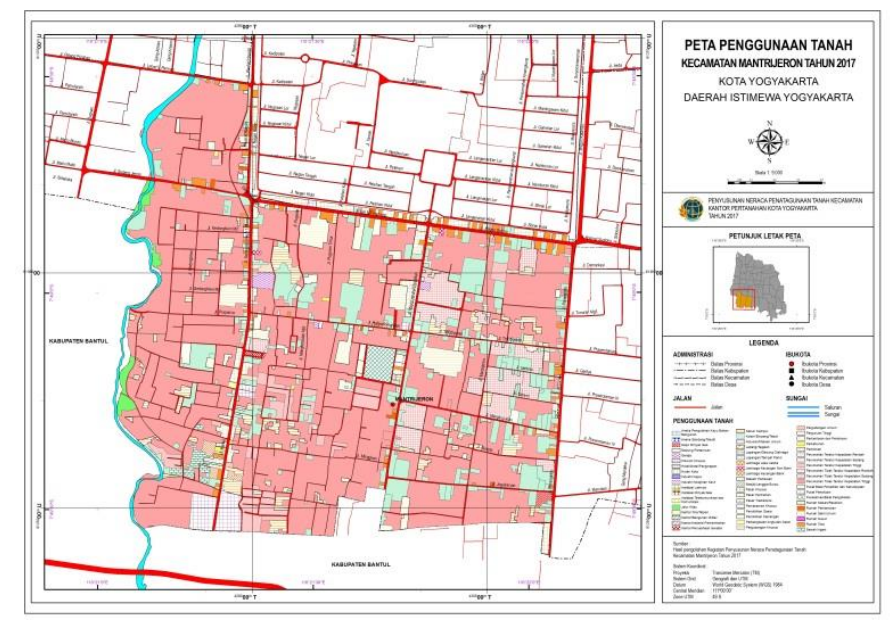

Gambar 3.3. Peta Penggunaan Tanah Kecamatan Mantrijeron Tahun 2017 


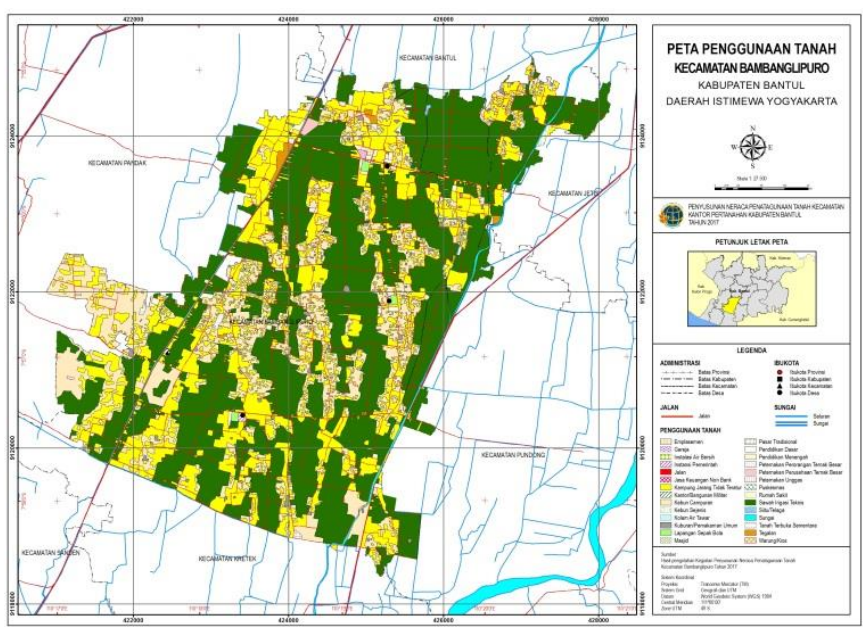

Gambar 3.4. Peta Penggunaan Tanah Kecamatan Bambanglipuro Tahun 2017

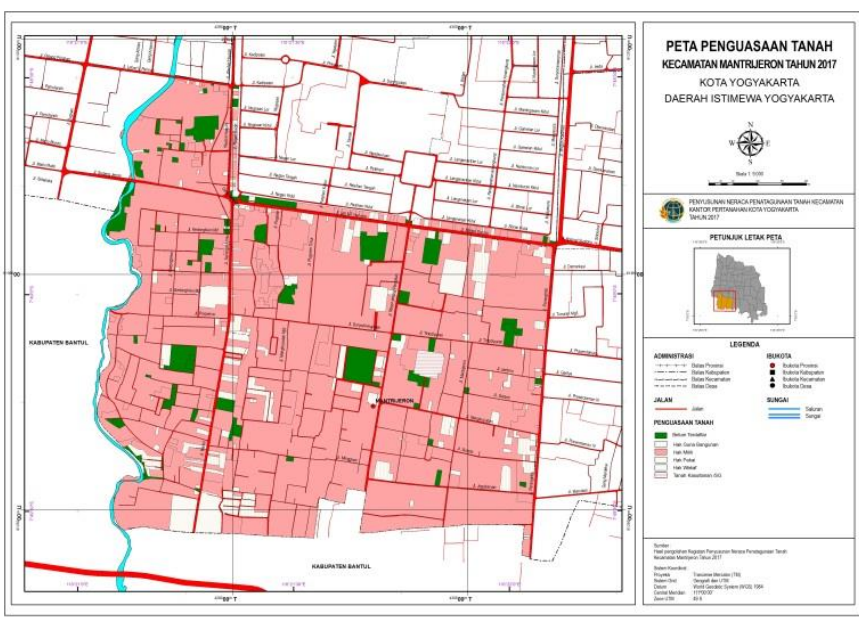

Gambar 3.5. Peta Penguasaan Tanah Kecamatan Mantrijeron Tahun 2017

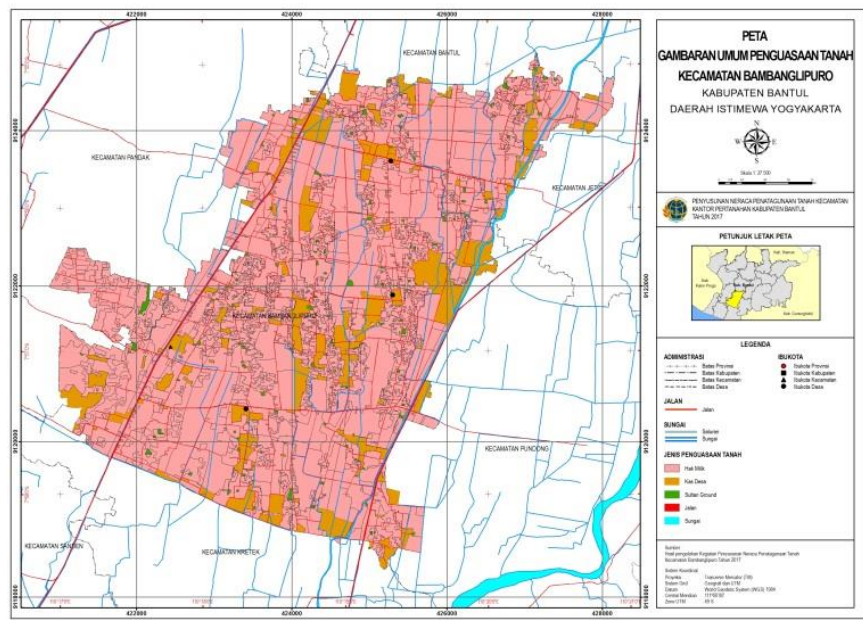

Gambar 3.6. Peta Penguasaan Tanah Kecamatan Bambanglipuro Tahun 2017

\subsection{Penyusunan hasil dan pembahasan}

Analisis perubahan penggunaan tanah

Analisis perubahan penggunaan tanah dilakukan untuk mengetahui luas dan lokasi perubahan penggunaan tanah dalam kurun waktu tertentu.
Untuk analisis perubahan penggunaan tanah di Kecamatan Mantrijeron menggunakan data penggunaan tanah tahun 2013 dan tahun 2017. Data penggunaan tanah Kecamatan Mantrijeron diperoleh dari hasil Penyusunan NPGT Kota Yogyakarta Tahun 2013 (Yogyakarta, 2013). Sementara Kecamatan Bambanglipuro menggunakan data penggunaan tanah tahun 2015 dan tahun 2017. Data penggunaan tanah Kecamatan Bambanglipuro diperoleh dari hasil Penyusunan NPGT Kabupaten Bantul Tahun 2015 (Yogyakarta, 2015). Data sebelum tahun 2017 disesuaikan dengan ketersediaan data di kantor pertanahan.

1. Kecamatan Mantrijeron

Berikut ini disajikan tabel perubahan penggunaan tanah Kecamatan Mantrijeron tahun 2013 dan tahun 2017.

Tabel 3.1. Perubahan Penggunaan Tanah Kecamatan Mantrijeron Tahun 2013 - 2017

\begin{tabular}{|c|c|c|c|c|c|c|}
\hline No & $\begin{array}{l}\text { Penggunaan Tanah Tahun } \\
2013\end{array}$ & $\begin{array}{l}\text { Luas } \\
\text { (Ha) }\end{array}$ & No & $\begin{array}{l}\text { Penggunaan Tanah Tahun } \\
2017\end{array}$ & \multicolumn{2}{|c|}{ Luas (Ha) } \\
\hline \multirow[t]{6}{*}{1} & Akomodasi Dan Rekreasi & 7,456 & 1 & Hotel/ Penginapan & 9,428 & $\frac{13,600}{1}$ \\
\hline & & & 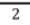 & Rumah Makan/Restoran & $\overline{1,272}$ & \\
\hline & & & 3 & Tempat Parkir & 0,266 & \\
\hline & & & 4 & Lapangan/Gedung Olah Raga & 1,172 & \\
\hline & & & 5 & Terminal Khusus & 0,774 & \\
\hline & & & 6 & $\begin{array}{l}\text { Aneka Pengolahan Kayu dan } \\
\text { Bahan Bangunan }\end{array}$ & 0,688 & \\
\hline \multirow[t]{2}{*}{2} & Industri Non Pertanian & 0,668 & 7 & Depo Minyak Gas & 0,587 & $\overline{0,722}$ \\
\hline & & & 8 & Perbengkelan Angkutan Darat & 0,135 & \\
\hline 3 & Jalan & 15,689 & 9 & Jalan & 15,689 & 15,689 \\
\hline 4 & Jasa Kesehatan & 2,657 & 10 & Puskesmas/ Balai Pengobatan & 0,727 & $\overline{0,727}$ \\
\hline 5 & Jasa Pelayanan Umum & 1,859 & 11 & $\begin{array}{l}\text { Instalasi Telekomunikasi dan } \\
\text { Komunikasi }\end{array}$ & 0,036 & $\overline{0,036}$ \\
\hline \multirow[t]{2}{*}{6} & Jasa Pemerintahan & 1,197 & 12 & Kantor/ Bangunan Militer & 0,109 & 2,031 \\
\hline & & & 13 & Kantor/Instansi Pemerintahan & 1,922 & \\
\hline \multirow[t]{3}{*}{7} & Jasa Pendidikan & 9,069 & 14 & Pendidikan Dasar & 2,188 & 10,446 \\
\hline & & & 15 & Pendidikan Menengah & $\overline{3,811}$ & \\
\hline & & & 16 & Perguruan Tinggi & 4,446 & \\
\hline \multirow[t]{2}{*}{8} & Jasa Peribadatan & $\begin{array}{ll}1,687 \\
\end{array}$ & 17 & Masjid & 1,423 & 2,267 \\
\hline & & & 18 & Gereja & $\overline{0.845}$ & \\
\hline \multirow[t]{3}{*}{9} & Lembaga Usaha & 0,165 & 19 & Kantor/ Perusahaan Swasta & 1,068 & 1,298 \\
\hline & & & 20 & Lembaga Keuangan Non Bank & 0,151 & \\
\hline & & & 21 & Lembaga Keuangan/ Bank & $\overline{0,079}$ & \\
\hline 10 & Makam Umum & 2,173 & 22 & Kuburan/Makam Umum & 2,939 & 2,939 \\
\hline \multirow{2}{*}{11} & Pasar & 3,343 & 23 & Pasar Khusus & 3,265 & 3,430 \\
\hline & & & 24 & Pasar Tradisional & $\overline{0,165}$ & \\
\hline \multirow[t]{5}{*}{12} & Perdagangan Umum & 28,215 & 25 & Pertokoan & 10,213 & 19,447 \\
\hline & & & 26 & Pusat Pertokoan & $\overline{0,521}$ & \\
\hline & & & 27 & Rumah Perkantoran & $\overline{0,419}$ & \\
\hline & & & 28 & Rumah Toko & 4,330 & \\
\hline & & & 29 & Warung/ Kios & $\overline{3,964}$ & \\
\hline \multirow[t]{2}{*}{13} & Pergudangan & 0,487 & 30 & Pergudangan Khusus & 0,368 & 1,307 \\
\hline & & & 31 & Pergudangan Umum & $\overline{0,939}$ & \\
\hline 14 & Pertanian Tanah Basah & 1,659 & 32 & Sawah Irigasi & 1,146 & 1,146 \\
\hline \multirow[t]{2}{*}{15} & Pertanian Tanah Kering & 1,519 & 33 & Kebun Campur & 9,222 & $\overline{9,403}$ \\
\hline & & & 34 & Perkebunan & $\overline{0,180}$ & \\
\hline 16 & $\begin{array}{l}\text { Perumahan Teratur } \\
\end{array}$ & 74,819 & 35 & $\begin{array}{l}\text { Perumahan Teratur Kepadatan } \\
\text { Tinggi }\end{array}$ & 6,987 & 6,987 \\
\hline \multirow{2}{*}{17} & Perumahan Tidak Teratur & 107,332 & 36 & $\begin{array}{l}\text { Perumahan Tidak Teratur } \\
\text { Kepadatan Sedang }\end{array}$ & 11,638 & 165,277 \\
\hline & & & 37 & $\begin{array}{l}\text { Perumahan Tidak Teratur } \\
\text { Kepadatan Tinggi }\end{array}$ & 153,639 & \\
\hline 18 & Sungai & 0,823 & 38 & Sungai & 0,823 & 0,823 \\
\hline \multirow[t]{4}{*}{19} & Tanah Kosong & 5,172 & 39 & $\begin{array}{l}\text { Tanah Kosong sudah ada } \\
\text { rencana peruntukannya }\end{array}$ & 5,057 & 5,057 \\
\hline & & & 40 & Jalur Hijau & 1,597 & 1,597 \\
\hline & & & 41 & Taman Kota & 1,764 & 1,764 \\
\hline & Jum & .991 & & Jumlal & 265,991 & 265,99 \\
\hline
\end{tabular}

Untuk klasifikasi penggunaan tanah Kecamatan Mantrijeron tahun 2013 menyesuaikan dengan aturan klasifikasi penggunaan tanah yang digunakan saat itu. Sehingga dibuat pengelompokan penggunaan tanah sebagaimana tabel di atas. Untuk tahun 2013 hanya terdapat 19 (sembilan belas) jenis penggunaan tanah, 
sementara untuk tahun 2017 terdapat 41 (empatpuluh satu) jenis penggunaan tanah (Bantul, 2017).

Jenis penggunaan tanah Akomodasi dan rekreasi mengalami peningkatan luas. Tahun 2017, penggunaan tanah untuk hotel/penginapan menjadi 9,428 Ha.

Penggunaan tanah untuk pertanian lahan basah menurun dari 1,659 Ha menjadi 1,146 Ha. Pengetatan izin perubahan penggunaan tanah pertanian menjadi non pertanian menjadi sebab penurunan luas sawah beririgasi relatif lambat.

Perumahan teratur dan perumahan tidak teratur pada tahun 2013 berjumlah 182,151 Ha, pada tahun 2017 menjadi 172,264 Ha. Hal ini disebabkan adanya perubahan penggunaan tanah di kawasan tersebut untuk akomodasi dan rekreasi, terutama hotel/penginapan.

Pertanian lahan kering di tahun 2017 luasnya meningkat. Peningkatan ini disebabkan oleh identifikasi penggunaan tanah yang lebih teliti, bukan disebabkan oleh aktifitas yang disengaja dalam rangka perluasan lahan pertanian.

Dalam klasifikasi penggunaan tanah tahun 2017 terdapat jenis penggunaan tanah jalur hijau dan taman kota. Keduanya merupakan bagian dari Ruang Terbuka Hijau (RTH). Pemerintah Kota Yogyakarta selama ini sudah berusaha untuk memperluas RTH guna memenuhi kuota 20\% (duapuluh persen) dari luas wilayah.

Peningkatan luas jasa peribadatan yang terdiri dari masjid dan gereja disebabkan oleh identifikasi penggunaan tanah yang lebih teliti.

Penurunan luas jasa kesehatan disebabkan oleh perbedaan identifikasi penggunaan tanah. Pada tahun 2013, lokasi tersebut diidentifkasi termasuk jasa kesehatan, sementara pada tahun 2017 lokasi tersebut diidentifikasi sebagai pendidikan tinggi khusus kesehatan.

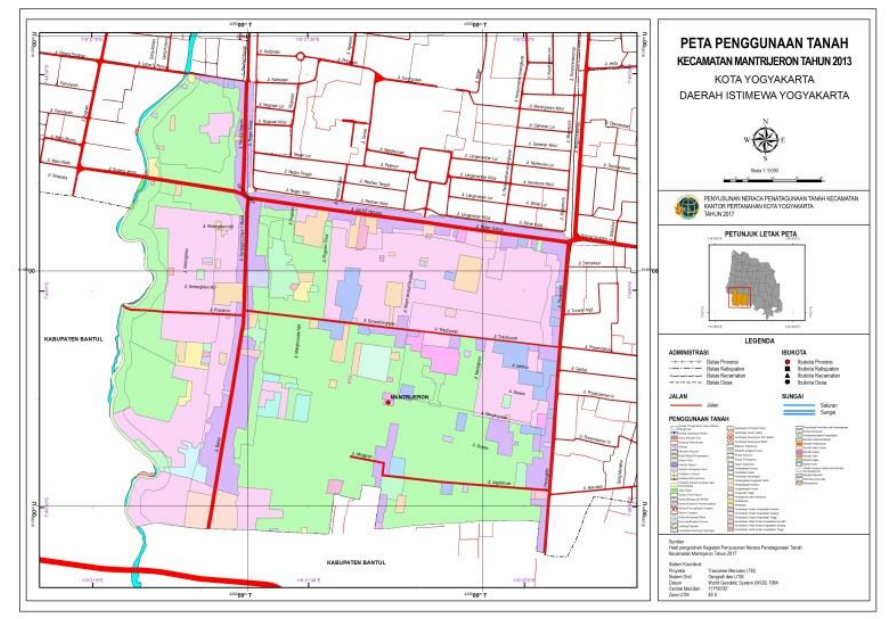

Gambar 3.7. Peta Penggunaan Tanah Kecamatan Mantrijeron Tahun 2013

Pola perubahan penggunaan tanah ditampilkan dalam Peta Perubahan Penggunaan Tanah pada Gambar 3.8.

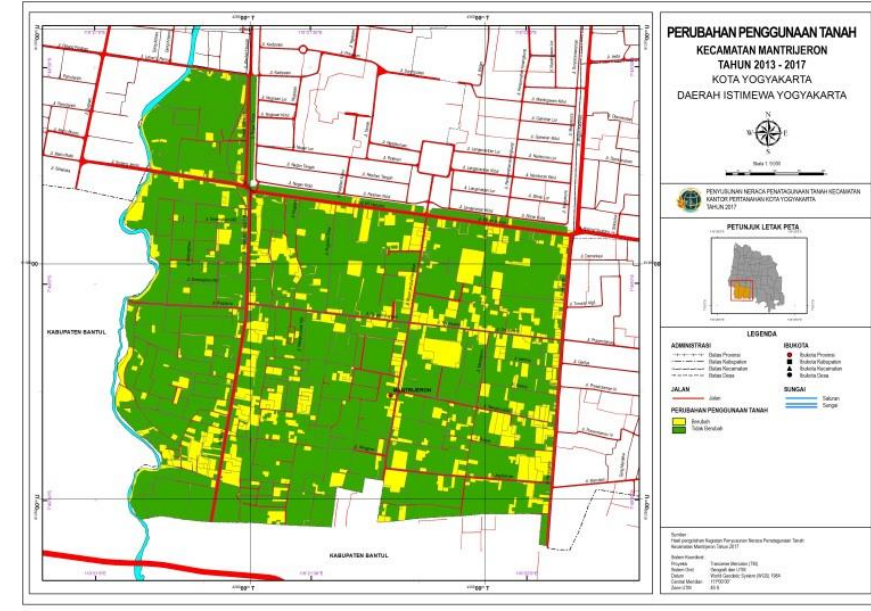

Gambar 3.8. Peta Perubahan Penggunaan Tanah Kecamatan Mantrijeron Tahun 2013-2017

Perubahan penggunaan tanah sebagian besar terjadi di sepanjang koridor Jalan Parangtritis, Jalan Bantul dan Jalan DI Panjaitan. Perubahan penggunaan relatif luas berada di bagian selatan Jalan Bantul dan Jalan Parangtritis. Pada kawasan tersebut, terutama Jalan Parangtritis merupakan kawasan pariwisata. Terdapat pembangunan hotel baru maupun pengembangan hotel-hotel lama pada ruas jalan tersebut.

Perubahan penggunaan tanah yang relatif luas terjadi akibat perbedaan identifikasi sebagaimana terjadi pada jasa kesehatan.

2. Kecamatan Bambanglipuro

Berikut ini disajikan tabel perubahan penggunaan tanah Kecamatan Bambanglipuro tahun 2015 dan tahun 2017.

Tabel 3.2. Rekapitulasi Perubahan Penggunaan Tanah Kecamatan Bambanglipuro Tahun 2015 - 2017

\begin{tabular}{|c|c|c|c|c|c|c|}
\hline \multirow[b]{2}{*}{ No } & \multirow[b]{2}{*}{ Penggunaan Tanah 2017} & \multicolumn{2}{|c|}{ Luas } & \multicolumn{3}{|c|}{ Perubahan Penggunaan Tanah } \\
\hline & & 2015 & 2017 & $\begin{array}{l}\text { Luas } \\
\text { (Ha) }\end{array}$ & $\begin{array}{c}\% \\
\text { Perubahan }\end{array}$ & $\begin{array}{c}\text { Rerata/ } \\
\text { tahun (Ha) }\end{array}$ \\
\hline 1 & Emplasemen & 1,235 & 1,356 & 0,121 & 0,005 & 0,06058 \\
\hline 2 & Gereja & 1,000 & 1,001 & 0,001 & 0,000 & 0,00027 \\
\hline 3 & Instalasi Air Bersih & 0,052 & 0,052 & 0,000 & 0,000 & 0,00001 \\
\hline 4 & Instansi Pemerintah & 2,550 & 2,550 & 0,000 & 0,000 & 0,00016 \\
\hline 5 & Jalan & 38,981 & 38,981 & 0,000 & 0,000 & $-0,00004$ \\
\hline 6 & Jasa Keuangan Non Bank & 0,084 & 0,084 & 0,000 & 0,000 & $-0,00005$ \\
\hline 7 & Kampung Jarang Tidak Teratur & 554,139 & 572,458 & 18,319 & 0,805 & 9,15966 \\
\hline 8 & Kantor/Bangunan Militer & 0,208 & 0,208 & 0,000 & 0,000 & 0,00002 \\
\hline 9 & Kebun Campuran & 400,974 & 401,067 & 0,093 & 0,004 & 0,04629 \\
\hline 10 & Kebun Sejenis & 1,920 & 1,920 & 0,000 & 0,000 & $-0,00001$ \\
\hline 11 & Kolam Air Tawar & 0,157 & 0,157 & 0,000 & 0,000 & 0,00020 \\
\hline 12 & Kuburan/Pemakaman Umum & 17,443 & 17,442 & $-0,001$ & 0,000 & $-0,00063$ \\
\hline$\overline{13}$ & Lapangan Sepak Bola & 3,315 & 3,316 & $\overline{0,001}$ & 0,000 & $\overline{0,00042}$ \\
\hline 14 & Masjid & 0,944 & 0,944 & 0,000 & 0,000 & 0,00023 \\
\hline 15 & $\begin{array}{l}\text { Pasar Tradisional } \\
\end{array}$ & 1,494 & 1,494 & 0,000 & 0,000 & $-0,00024$ \\
\hline$\overline{16}$ & $\begin{array}{l}\text { Pendidikan Dasar } \\
\end{array}$ & 5,587 & 5,586 & $-0,001$ & 0,000 & $-0,00048$ \\
\hline 17 & Pendidikan Menengah & 5,276 & 5,276 & 0,000 & 0,000 & $-0,00009$ \\
\hline 18 & Peternakan Perorangan Ternak Besar & 10,693 & 8,008 & $-2,685$ & 0,118 & $-1,34273$ \\
\hline 19 & Peternakan Perusahaan Ternak Besar & . & 2,686 & 2,686 & 0,118 & 1,34310 \\
\hline 20 & Peternakan Unggas & 0,506 & 0,758 & 0,252 & 0,011 & 0,12612 \\
\hline 21 & $\begin{array}{ll}\text { Puskesmas } \\
\text { Pus }\end{array}$ & 0,673 & 0,673 & 0,000 & 0,000 & $-0,00003$ \\
\hline 22 & Rumah Sakit & 0,415 & 0,415 & 0,000 & 0,000 & $\overline{0,00012}$ \\
\hline 23 & Sawah Irigasi Teknis & $1.198,416$ & $1.178,420$ & $-19,996$ & 0,879 & $-9,99817$ \\
\hline 24 & Situ/Telaga & - & 0,515 & 0,515 & 0,023 & 0,25774 \\
\hline 25 & Sungai & 20,497 & 20,496 & $-0,001$ & 0,000 & $-0,00045$ \\
\hline 26 & Tanah Terbuka Sementara & 0,784 & 0,784 & 0,000 & 0,000 & 0,00014 \\
\hline 27 & Tegalan & 7,941 & 8,278 & 0,337 & 0,015 & 0,16873 \\
\hline 28 & Warung/Kios & 0,084 & 0,441 & 0,357 & 0,016 & 0,17844 \\
\hline & Jumlah & $2.275,368$ & $2.275,367$ & 45,370 & 1,994 & 22,685 \\
\hline
\end{tabular}


Jenis penggunaan tanah tahun 2015 tidak jauh berbeda dengan tahun 2017. Untuk tahun 2015 terdapat 26 (duapuluh enam) jenis penggunaan tanah, sementara untuk tahun 2017 terdapat 28 (duapuluh delapan) jenis penggunaan tanah.

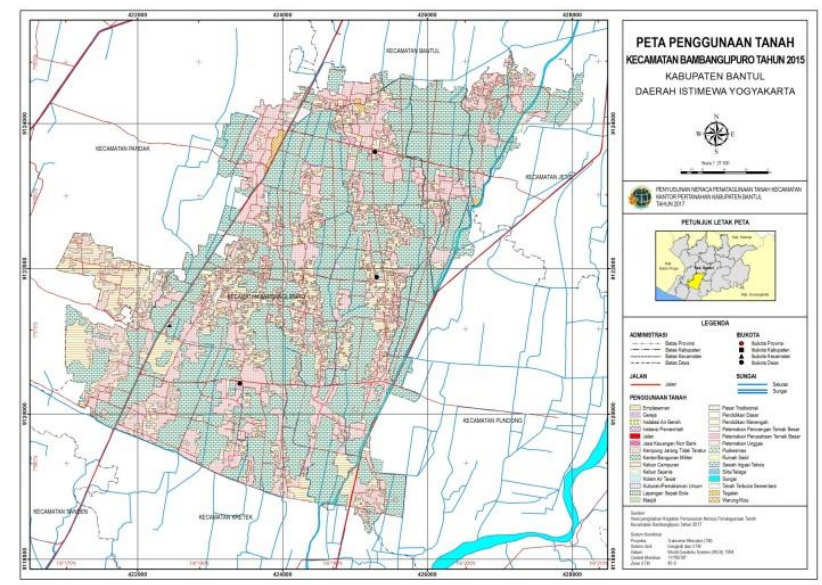

Gambar 3.9. Peta Penggunaan Tanah

Kecamatan Bambanglipuro Tahun 2015

Berdasarkan dari Tabel 3.2. dapat dilihat bahwa perubahan penggunaan tanah di Kecamatan Bambanglipuro selama 2 (dua) tahun, dari tahun 20152017 seluas 45,370 $\mathrm{Ha}$ atau sebesar 1,99\% sehingga ratarata perubahan penggunaan tanah di Kecamatan Bambanglipuro per tahun adalah 22,685 $\mathrm{Ha}$.

Perubahan penggunaan tanah terbesar adalah sawah irigasi teknis menjadi kampung jarang tidak teratur. Perubahan lainnya adalah peternakan perorangan ternak besar menjadi peternakan perusahaan ternak besar.

Berdasarkan peta perubahan penggunaan tanah, perubahan penggunaan tanah sebagian besar terjadi di koridor jalan, terutama di Jalan Samas. Hal ini tidak lepas oleh kebutuhan rumah tinggal yang meningkat seiring dengan meningkatnya jumlah penduduk di Kecamatan Bambanglipuro.

Pola perubahan penggunaan tanah ditampilkan pada Peta Perubahan Penggunaan Tanah.

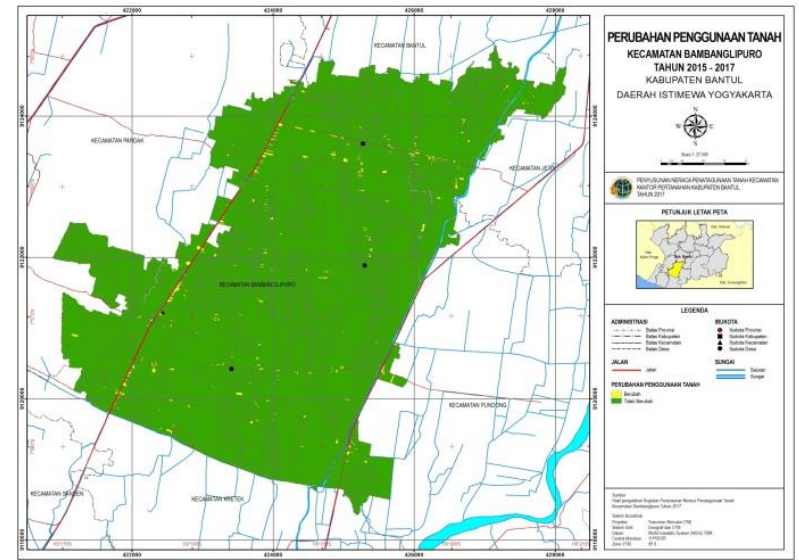

Gambar 3.10. Peta Perubahan Penggunaan Tanah Kecamatan Bambanglipuro Tahun 2015-2017

\section{Analisis kesesuaian penggunaan tanah}

1. Kecamatan Mantrijeron

Kecamatan Mantrijeron sudah memiliki peraturan daerah tentang RDTR sehingga analisis kesesuaian penggunaan tanah dilakukan terhadap RDTR.

Rencana Detail Tata Ruang (RDTR) adalah rencana pemanfaatan ruang kota yang disusun secara terinci untuk penyiapan perwujudan ruang dalam rangka pelaksanaan program-program pembangunan kota Penyusunan RDTR didasarkan pada upaya untuk mewujudkan tujuan penataan ruang wilayah Kota Yogyakarta, yang diterjemahkan dalam kebijakan dan strategi pengembangan struktur ruang dan pola ruang wilayah Kota Yogyakarta. RDTR memuat rumusan kebijaksanaan pemanfaatan ruang kota yang disusun dan ditetapkan untuk menyiapkan perwuudan ruang Bagian Wilayah Kota dalam rangka pelaksanaan program dan pengendalian pembangunan kota baik yang dilakukan oleh Pemerintah, swasta maupun masyarakat.

Peraturan Daerah Nomor 1 Tahun 2015 tentang Rencana Detail Tata Ruang dan Peraturan Zonasi Kota Yogyakarta Tahun 2015-2035, disusun dalam rangka mewujudkan Kota Yogyakarta yang produktif dan berkualitas dengan memanfaatkan potensi budaya dan pendidikan berkualitas serta pariwisata dan jasa secara efisien serta berkelanjutan, maka diperlukan rencana rinci yang operasional dan implementatif serta aplikatif terhadap kegiatan pengendalian pembangunan sehingga dapat mendukung penataan dan pengendalian pembangunan Kota Yogyakarta (Yogyakarta, 2017).

Berikut ini pembagian pola ruang di wilayah Kecamatan Mantrijeron berbasis RDTR Kecamatan Mantrijeron.

Tabel 3.3. Rencana pola ruang di Kecamatan Mantrijeron

\begin{tabular}{clrr}
\hline No & Rencana Pola Ruang & Luas (Ha) & \multicolumn{1}{c}{ Persentase } \\
\hline 1 & Perdagangan dan Jasa & 35,795 & 13,46 \\
\hline 2 & Perumahan Kepadatan Sedang & 144,402 & 54,29 \\
\hline 3 & Perumahan Kepadatan Tinggi & 63,868 & 24,01 \\
\hline 4 & RTH Fungsi Tertentu & 2,470 & 0,93 \\
\hline 5 & RTH Taman, Hutan Kota, Lapangan Olahraga & 1,707 & 0,64 \\
\hline 6 & Sarana Pendidikan & 1,241 & 0,47 \\
\hline 7 & Sempadan Sungai & 0,710 & 0,27 \\
\hline 8 & Jalan & 14,975 & 5,63 \\
\hline 9 & Sungai & 0,823 & 0,31 \\
\hline & & $\mathbf{2 6 5 , 9 9 1}$ & $\mathbf{1 0 0 , 0 0}$ \\
\hline
\end{tabular}

Kesesuaian penggunaan tanah dengan RDTR yang dimaksud adalah kesesuaian penggunaan tanah berdasarkan pola ruang yang dijabarkan dalam peraturan zonasi (zona dan sub zona) dalam RDTR. Zona dan sub zona tersebut terbagi menjadi zona/subzona kawasan lindung dan zona/subzona kawasan budidaya. Setiap zona/subzona diatur kegiatan yang diizinkan, diizinkan terbatas, diizinkan bersyarat dan tidak diizinkan. Klasifikasi kesesuaian penggunaan tanah disajikan dalam tabel dan peta dibawah ini. 
Tabel 3.4. Kesesuaian penggunaan tanah Kecamatan Mantrijeron terhadap RDTR dan Peraturan Zonasi

\begin{tabular}{rlrr}
\hline \multirow{2}{*}{ No } & \multirow{2}{*}{ Analisis Penggunaan Tanah terhadap RDTR } & \multicolumn{2}{c}{ Luas } \\
\cline { 3 - 4 } & & (Ha) & Persentase \\
\hline 1 & Pemanfaatan Diizinkan & 222,928 & 83,81 \\
\hline 2 & Pemanfaatan Diizinkan Secara Terbatas & 11,241 & 4,23 \\
\hline 3 & Pemanfaatan Memerlukan Izin Penggunaan Bersyarat & 11,363 & 4,27 \\
\hline 4 & Pemanfaatan Tidak Diizinkan & 3,946 & 1,48 \\
\hline 5 & Jalan & 15,689 & 5,90 \\
\hline 6 & Sungai & 0,823 & 0,31 \\
\hline & Jumlah & $\mathbf{2 6 5 , 9 9 1}$ & $\mathbf{1 0 0 , 0 0}$ \\
\hline
\end{tabular}

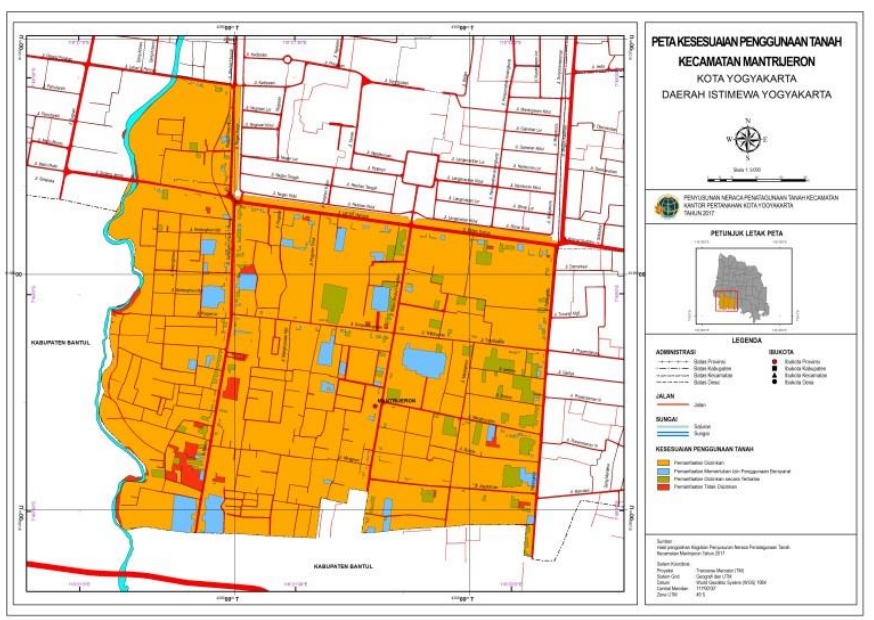

Gambar 3.11. Peta kesesuaian penggunaan tanah Kecamatan Mantrijeron tahun 2017

Klasifikasi kesesuaian penggunaan tanah terhadap RDTR sesuai peraturan zonasi dikelompokkan menjadi :

a. I (Pemanfaatan diizinkan), apabila penggunaan/ pemanfaatan ruang yang memiliki sifat sesuai dengan peruntukan ruang yang direncanakan

b. T (Pemanfaatan diizinkan secara terbatas), apabila penggunaan/ pemanfaatan ruang diperlukan persyaratan secara terbatas baik dalam pembatasan waktu, intensitas ruang (KDB, $\mathrm{KLB}, \mathrm{KDH}$, ketinggian bangunan), dan pembatasan luas pemanfaatan ruang.

c. B (Pemanfaatan memerlukan izin penggunaan bersyarat, apabila penggunaan/ pemanfaatan tanah diperlukan persyaratan tertentu dalam rangka pemanfaatan ruang (AMDAL, UKL. UPL, ANDALIN).

d. X (Pemanfaatan yang tidak diizinkan), apabila penggunaan/ pemanfaatan tanah yang tidak sesuai dengan peruntukan yang direncanakan dan dapat menimbulkan dampak yang cukup besar bagi lingkungan di sekitarnya

Arahan pola ruang terluas di Kecamatan Mantrijeron adalah untuk perumahan sebesar 208,27 atau 78,30\% yang terdiri dari perumahan kepadatan sedang seluas 144,402 Ha atau 54,29\% dan perumahan kepadatan tinggi seluas 63,868 $\mathrm{Ha}$ atau 24,01\%. Luasan berikutnya adalah perdagangan dan jasa seluas $35,795 \mathrm{Ha}$ atau $13,46 \%$.
Hasil analisis kesesuaian penggunaan tanah terdapat $222,928 \mathrm{Ha}$ atau $83,81 \%$ pemanfaatan diizinkan. Pemanfaatan diizinkan secara terbatas seluas 11,241 $\mathrm{Ha}$ atau $4,23 \%$ dan pemanfaatan memerlukan izin penggunaan bersyarat seluas 11,363 Ha atau 4,27\%.

Sementara terdapat 3,946 $\mathrm{Ha}$ atau 1,48\%, pemanfaatan tidak diizinkan. Pemanfaatan tidak diizinkan terdapat di beberapa lokasi di Jalan Bantul. Selain itu terdapat di kawasan sempadan sungai.

2. Kecamatan Bambanglipuro

Kecamatan Bambanglipuro belum memiliki RDTR dan baru disusun kajian teknisnya pada tahun anggaran 2017 oleh Pemerintah Kabupaten Bantul. Untuk itu, analisis tata ruang dalam Penyusunan Neraca Penatagunaan Tanah Kecamatan Bambanglipuro menggunakan dokumen Rencana Tata Ruang Wilayah Kabupaten Bantul.

Berikut ini pembagian pola ruang di wilayah Kecamatan Bambanglipuro berbasis RTRW Kabupaten Bantul.

Tabel 3.4. Rencana pola ruang di Kecamatan Bambanglipuro

\begin{tabular}{|c|c|c|c|}
\hline No & Zona & Luas (Ha) & Persentase \\
\hline 1 & Campuran & 25,938 & 1,14 \\
\hline 2 & Perdagangan Jasa & 69,807 & 3,07 \\
\hline 3 & Permukiman & 938,656 & 41,25 \\
\hline 4 & Pertanian Lahan Basah & 677,727 & 29,79 \\
\hline 5 & Pertanian Lahan Kering & 430,951 & 18,94 \\
\hline 6 & Sempadan Sungai & 72,809 & 3,20 \\
\hline 7 & Jalan & 38,981 & 1,71 \\
\hline \multirow[t]{2}{*}{8} & Sungai & 20,496 & 0,90 \\
\hline & Jumlah & $2.275,365$ & 100,00 \\
\hline
\end{tabular}

Kesesuaian penggunaan tanah dengan tata ruang kabupaten/kota yang dimaksud adalah kesesuaian penggunaan tanah berdasarkan pola ruang dalam dokumen Tata Ruang Kabupaten/Kota. Dalam dokumen RTRW terdapat arahan kegiatan pembangunan. Arahan kegiatan/pembangunan digunakan sebagai referensi untuk kesesuaian penggunaan tanah terhadap RTRW.

Kelas kesesuaian penggunaan tanah yang digunakan adalah :

a. Sesuai, bila penggunaan tanah sesuai dengan arahan pola ruang.

b. Tidak sesuai, bila penggunaan tanah tidak direkomendasikan dalam arahan pola ruang.

Kesesuaian penggunaan tanah di Kecamatan Bambanglipuro pada tahun 2017 terhadap Rencana Tata Ruang Wilayah Kabupaten Bantul wilayah Kecamatan Bambanglipuro tercantum pada Tabel 3.5. 
Tabel 3.5. Kesesuaian Penggunaan Tanah terhadap RTRW di Kecamatan Bambanglipuro

\begin{tabular}{|c|c|c|c|c|c|c|}
\hline \multirow{3}{*}{ No } & \multirow{3}{*}{ RTRW } & \multicolumn{4}{|c|}{ Kesesuaian Penggunaan Tanah thd RTRW } & \multirow{3}{*}{ Jumlah } \\
\hline & & \multicolumn{2}{|c|}{ Sesuai } & \multicolumn{2}{|c|}{ Tidak Sesuai } & \\
\hline & & На & $\%$ & На & $\%$ & \\
\hline 1 & Campuran & 20,054 & 0,88 & 5,885 & 0,26 & 25,939 \\
\hline 2 & Perdagangan dan Jasa & 30,488 & 1,34 & 39,319 & 1,73 & 69,807 \\
\hline 3 & Permukiman & 938,044 & 41,23 & $\overline{0,612}$ & $\overline{0,03}$ & 938,656 \\
\hline 4 & Pertanian Lahan Basah & 625,940 & 27,51 & 51,787 & 2,28 & 677,727 \\
\hline 5 & Pertanian Lahan Kering & 350,451 & 15,40 & 80,499 & 3,54 & 430,951 \\
\hline 6 & Sempadan Sungai & 59,656 & 2,62 & 13,153 & 0,58 & 72,809 \\
\hline 7 & Jalan & & $\overline{0,00}$ & & 0,00 & 38,981 \\
\hline 8 & Sungai & & 0,00 & & 0,00 & 20,496 \\
\hline & Jumlah & $2.024,633$ & 88,98 & 191,256 & $\mathbf{8 , 4 1}$ & $2.275,367$ \\
\hline
\end{tabular}

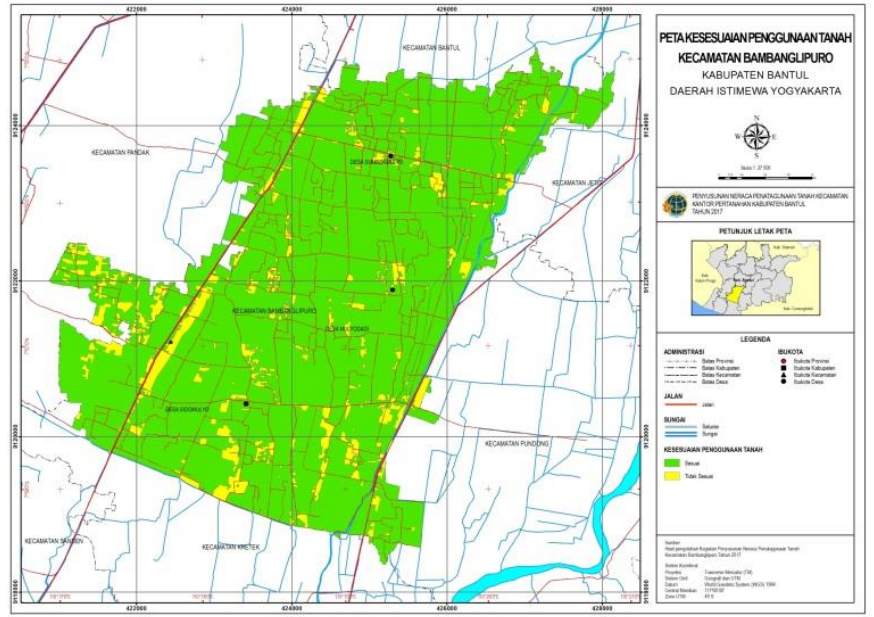

Gambar 3.12. Peta kesesuaian penggunaan tanah Kecamatan Bambanglipuro tahun 2017

Arahan pola ruang di Kecamatan Bambanglipuro sebagian besar adalah permukiman seluas 938,656 Ha atau 41,25\%. Selanjutnya adalah arahan pertanian lahan basah seluas 677,727 Ha atau 29,79\% dan pertanian lahan kering seluas $18,94 \%$. Secara kumulatif, arahan pola ruang untuk pertanian adalah yang terluas, yaitu 1.108,678 Ha atau $48,73 \%$ dari luas wilayah Kecamatan Bambanglipuro. Arahan pola ruang perdagangan dan jasa hanya seluas 69,807 Ha atau 3,07\%.

Dari data kesesuaian penggunaan tanah diatas, dapat ditarik kesimpulan bahwa penggunaan tanah di Kecamatan Bambanglipuro pada tahun 2017 sebagian besar adalah sesuai, yaitu seluas $2.024,633 \mathrm{Ha}$ atau sebesar 88,98\% dari luas wilayah Kecamatan Bambanglipuro, sementara penggunaan tanah yang tidak sesuai sebesar 191,256 Ha atau 8,41\% dari luas wilayah Kecamatan Bambanglipuro. Sedangkan sisanya seluas 38,981 Ha digunakan untuk jalan, dan seluas 20,496 На merupakan sungai.

\section{Analisis ketersediaan tanah}

1. Kecamatan Mantrijeron

Analisis ketersediaan tanah dilakukan untuk mengetahui kebutuhan dan ketersediaan tanah yang dapat digunakan untuk kegiatan tertentu berdasarkan kesesuaian penggunaan tanah dan penguasaan/pemilikan tanah. Untuk memperoleh informasi ketersediaan tanah terhadap kecamatan yang telah tersedia RDTR, dilakukan overlay hasil analisa kesesuaian penggunaan tanah terhadap RDTR (diizinkan, diizinkan terbatas, diizinkan bersyarat dan tidak diizinkan) dengan peta administrasi dan peta penguasaan/pemilikan tanah. Analisa ketersediaan tanah yang dilaksanakan adalah analisa prioritas ketersediaan tanah. Tanah-tanah yang belum digunakan secara intensif dan belum dikuasai dengan hak atas tanah (skala besar) dikategorikan sebagai tanah-tanah yang tersedia untuk berbagai kegiatan sesuai dengan tata ruang. Sedangkan tanah-tanah yang telah digunakan secara intensif dan telah dikuasai dengan hak atas tanah (skala besar) masih dikategorikan tersedia dalam rangka penyesuaian dan optimalisasi penggunaan tanah.

Berikut ini hasil pengolahan data dan peta ketersediaan tanah di Kecamatan Mantrijeron.

Tabel 3.6. Matrik Ketersediaan Tanah di Kecamatan Mantrijeron berdasarkan RDTR dan Peraturan Zonasi

\begin{tabular}{|c|c|c|c|}
\hline \multirow{2}{*}{ No } & \multirow{2}{*}{ Ketersediaan Tanah } & \multicolumn{2}{|l|}{ Luas } \\
\hline & & (Ha) & Persentase \\
\hline 1 & $\begin{array}{l}\text { Penggunaan/Pemanfaatan Tanah Diizinkan Dalam } \\
\text { Tanah Yang Belum Terdaftar }\end{array}$ & 12,823 & 4,82 \\
\hline 2 & $\begin{array}{l}\text { Penggunaan/Pemanfaatan Tanah Diizinkan Dalam } \\
\text { Tanah Yang Sudah Terdaftar }\end{array}$ & 210,105 & 78,99 \\
\hline 3 & $\begin{array}{l}\text { Penggunaan/Pemanfaatan Tanah Diizinkan Secara } \\
\text { Terbatas Dalam Tanah Yang Belum Terdaftar }\end{array}$ & 0,054 & 0,02 \\
\hline 4 & $\begin{array}{l}\text { Penggunaan/Pemanfaatan Tanah Diizinkan Secara } \\
\text { Terbatas Dalam Tanah Yang Sudah Terdaftar }\end{array}$ & 11,187 & 4,21 \\
\hline 5 & $\begin{array}{l}\text { Penggunaan/Pemanfaatan Tanah Diizinkan Bersyarat } \\
\text { Dalam Tanah Yang Belum Terdaftar }\end{array}$ & 0,738 & 0,28 \\
\hline 6 & $\begin{array}{l}\text { Penggunaan/Pemanfaatan Tanah Diizinkan Bersyarat } \\
\text { Dalam Tanah Yang Sudah Terdaftar }\end{array}$ & 10,625 & 3,99 \\
\hline 7 & $\begin{array}{l}\text { Penggunaan/Pemanfaatan Tanah Tidak Diizinkan } \\
\text { Dalam Tanah Yang Belum Terdaftar }\end{array}$ & 0,087 & 0,03 \\
\hline 8 & $\begin{array}{l}\text { Penggunaan/Pemanfaatan Tanah Tidak Diizinkan } \\
\text { Dalam Tanah Yang Sudah Terdaftar }\end{array}$ & 3,859 & 1,45 \\
\hline 9 & Jalan & 15,689 & 5,90 \\
\hline 10 & Sungai & 0,823 & 0,31 \\
\hline & Jumlah & 265,991 & 100,00 \\
\hline
\end{tabular}

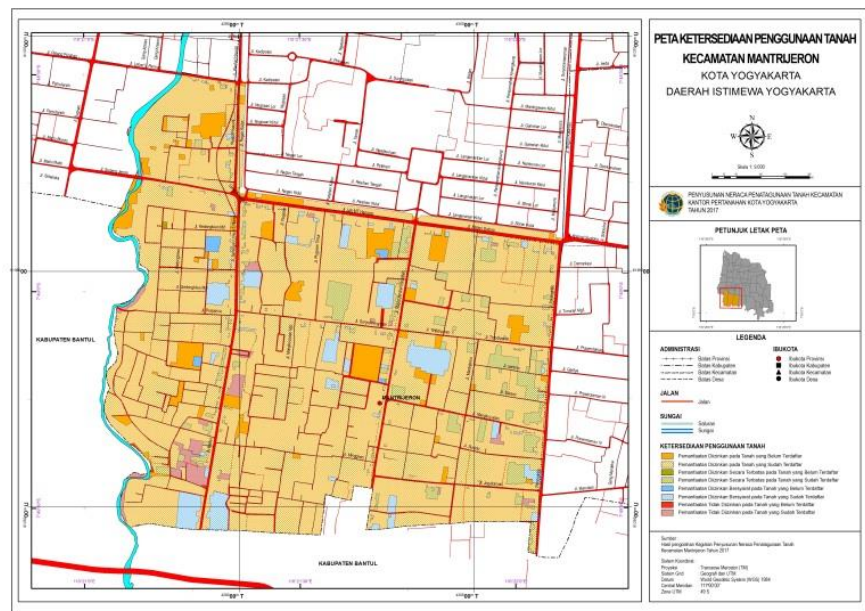

Gambar 3.13. Peta ketersediaan penggunaan tanah Kecamatan Mantrijeron tahun 2017

Sesuai matrik ketersediaan di atas sebagian besar adalah penggunaan/pemanfaatan tanah diizinkan dalam tanah yang sudah terdaftar seluas 210,105 Ha atau $78,99 \%$ dan dalam tanah yang belum terdaftar seluas 12,823 Ha atau 4,82\%. Sehingga 
penggunaan/pemanfaatan diizinkan seluas 222,928 Ha atau $83,81 \%$.

2. Kecamatan Bambanglipuro

Analisis ketersediaan tanah untuk Kecamatan Bambanglipuro pada dasarnya sama dengan pengolahan data pada Kecamatan Mantrijeron. Perbedaannya adalah di Kecamatan Bambanglipuro overlay dilakukan terhadap RTRW dan Peta Wilayah Tanah Usaha.

Seluruh wilayah Kecamatan Bambanglipuro termasuk WTU Utama Iabc, sehingga untuk penggunaan tanah Sesuai potensi zonasinya diizinkan, dan penggunaan tanah Tidak Sesuai potensi zonasinya diizinkan/diperbolehkan terbatas/bersyarat.

Hasil pengolahan data dan peta ketersediaan tanah di Kecamatan Bambanglipuro ditampilkan di bawah ini.

Tabel 3.7. Matrik Ketersediaan Tanah di Kecamatan Bambanglipuro berdasarkan RTRW

\begin{tabular}{rlrr}
\hline \multirow{2}{*}{ No } & \multirow{2}{*}{ Ketersediaan Tanah } & \multicolumn{2}{c}{ Luas } \\
\cline { 3 - 4 } & & \multicolumn{1}{c}{ (Ha) } & Persentase \\
\hline 1 & Pemanfaatan Diizinkan Dalam Tanah Yang Belum Terdaftar & 655,821 & 28,82 \\
\hline 2 & Pemanfaatan Diizinkan Dalam Tanah Yang Terdaftar & 1368,812 & 60,16 \\
\hline 3 & Pemanfaatan Diizinkan Secara Terbatas Dalam Tanah Yang Belum Terdaftar & 73,360 & 3,22 \\
\hline 4 & Pemanfaatan Diizinkan Secara Terbatas Dalam Tanah Yang Terdaftar & 117,896 & 5,18 \\
\hline 5 & Pemanfaatan Diizinkan Bersyarat Dalam Tanah Yang Belum Terdaftar & 0,000 & 0,00 \\
\hline 6 & Pemanfaatan Diizinkan Bersyarat Dalam Tanah Yang Terdaftar & 0,000 & 0,00 \\
\hline 7 & Pemanfaatan Tidak Diizinkan Dalam Tanah Yang Belum Terdaftar & 0,000 & 0,00 \\
\hline 8 & Pemanfaatan Tidak Diizinkan Dalam Tanah Yang Terdaftar & 0,000 & 0,00 \\
\hline 9 & Jalan & 38,981 & 1,71 \\
\hline 10 & Sungai & 20,496 & 0,90 \\
\hline & & $\mathbf{2 . 2 7 5 , 3 6 7}$ & $\mathbf{1 0 0 , 0 0}$ \\
\hline
\end{tabular}

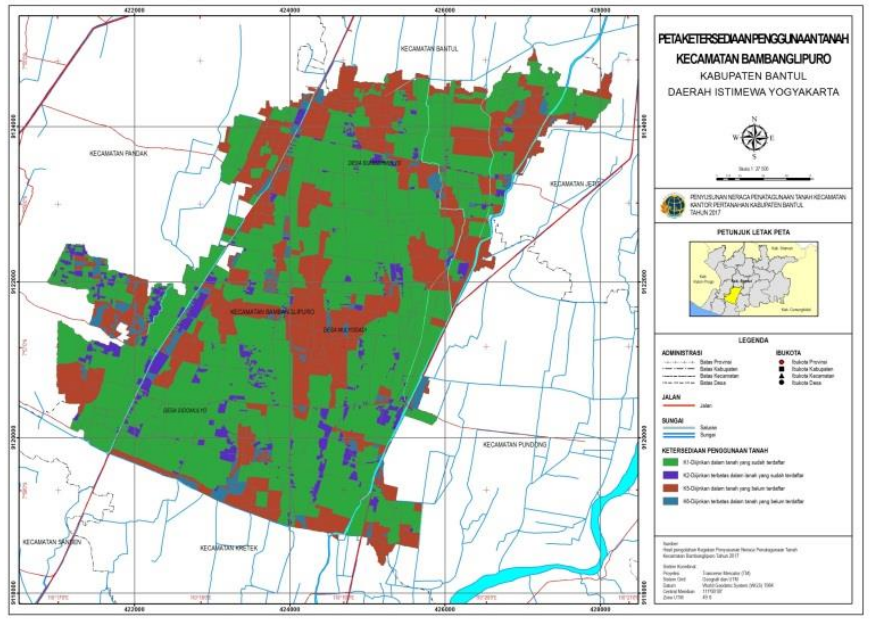

Gambar 3.14. Peta ketersediaan penggunaan tanah Kecamatan Bambanglipuro tahun 2017

Sesuai matrik ketersediaan di atas sebagian besar adalah pemanfaatan diizinkan dalam tanah yang terdaftar seluas $1.368,812 \mathrm{Ha}$ atau $60,16 \%$. Sementara pemanfaatan diizinkan dalam tanah yang belum terdaftar seluas $655,821 \mathrm{Ha}$ atau $28,82 \%$. Sehingga jumlah pemanfaatan diizinkan seluas 2.024,633 Ha atau $88,98 \%$. Berdasarkan matrik tersebut di atas pemanfaatan diizinkan bersyarat dan pemanfaatan tidak diizinkan tidak ada, baik dalam tanah yang terdaftar maupun dalam tanah yang belum terdaftar.

Hasil analisa prioritas ketersediaan tanah pada 2 (dua) kecamatan adalah sebagai berikut :

a. Tanah tersedia untuk berbagai kegiatan sesuai dengan tata ruang.

Kategori ini adalah tanah yang belum digunakan secara intensif dan belum dikuasai dengan hak atas tanah (skala besar).

b. Tersedia dalam rangka optimalisasi penggunaan tanah.

Untuk tanah yang tersedia dalam rangka optimalisasi penggunaan tanah, pada tanah tersebut sudah ada penguasaan tanah dan penggunaan tanahnya sudah sesuai dengan arahan RDTR/RTRW serta perlu dilaksanakan optimalisasi terhadap penggunaan yang sudah ada.

c. Tersedia dalam rangka penyesuaian penggunaan tanah

Untuk tanah yang tersedia dalam rangka penyesuaian penggunaan tanah, pada tanah tersebut sudah ada penguasaan tanah tetapi penggunaan tanahnya tidak sesuai dengan fungsi kawasan dalam RTRW serta masih diperlukan adanya penyesuaian penggunaan tanah.

d. Tidak tersedia

Untuk tanah yang tidak tersedia adalah tanah untuk jalan dan untuk sungai.

\section{Perbandingan 2 (dua) kawasan}

1. Penyiapan peta kerja

Cakupan peta bidang tanah di Kecamatan Mantrijeron lebih dari 95\% dan Kecamatan Bambanglipuro lebih dari 80\%. Sehingga di wilayah Kecamatan Bambanglipuro terdapat blank area akibat belum terpetakan.

2. Pengumpulan data primer dan data pendukung

Dari pengumpulan data primer berupa peta penggunaan tanah diketahui bahwa dalam satu bidang tanah dapat ditemukan penggunaan tanah lebih dari 1 (satu) jenis.

Untuk wilayah perkotaan ditemukan di sepanjang koridor jalan, dimana bagian depan digunakan untuk perdagangan dan jasa dan bagian belakang digunakan untuk permukiman. Di wilayah perdesaan ditemukan pada kawasan permukiman yang bercampur dengan kebun campuran, tanah terbuka, emplasemen dan lainnya.

Jenis penggunaan tanah di kawasan perkotaan lebih banyak daripada di kawasan perdesaan.

Bidang-bidang tanah di kawasan perkotaan luasannya relatif kecil dibanding dengan kawasan perdesaan.

3. Analisis perubahan penggunaan tanah

Sebaran perubahan penggunaan tanah relatif sama, yaitu di sepanjang koridor jalan utama.

4. Analisis kesesuaian penggunaan tanah

Kecamatan Mantrijeron sudah menggunakan RDTR sehingga klasifikasi kesesuaian penggunaan tanah 
terhadap RDTR sesuai peraturan zonasi. Sedangkan Kecamatan Bambanglipuro menggunakan RTRW sehingga klasifikasi kesesuaian penggunaan tanah menggunakan WTU.

Kesesuaian penggunaan tanah terhadap RTRW/RDTR di kedua wilayah lebih dari $80 \%$.

5. Analisis ketersediaan tanah

Di kedua wilayah, berdasarkan matrik ketersediaan tanah sebagian besar adalah pemanfaatan diizinkan yang mencapai lebih dari $80 \%$.

\section{Kesimpulan}

Penyusunan NPGT berbasis peta bidang tanah menyediakan informasi penguasaan dan pemilikan tanah yang sangat rinci. Bidang-bidang tanah tersebut selanjutnya menjadi acuan dalam penyusunan peta penggunaan tanah. Bahwa dalam penyusunan NPGT yang berbasis zona, peta penggunaan tanah menjadi acuan dalam penyusunan peta-peta lainnya.

Peta bidang tanah selanjutnya digunakan sebagai acuan terhadap peta RDTR maupun RTRW. Dalam rangka analisis spasial maka dilakukan koreksi dan atau penyesuaian peta-peta RDTR dan RTRW agar sesuai dengan peta bidang tanah.

Dalam proses analisis ditemukan beberapa penggunaan tanah yang tidak sesuai dengan arahan fungsi kawasan dalam RDTR yang disebabkan oleh RDTR belum dibuat berdasarkan persil dan blok melainkan dibuat dengan ditarik garis lurus, maka ada beberapa kegiatan yang berada tidak pada satu zona namun masuk pada dua zona atau lebih. Ini mengakibatkan pada satu bangunan sebagian masuk zona diizinkan tapi sebagian lainnya masuk dalam klasifikasi zona pemanfaatan tanah yang diizinkan secara terbatas, pemanfaatan memerlukan izin penggunaan bersyarat atau tidak diizinkan.

Bahwa dengan ketersediaan peta bidang tanah di kantor-kantor pertanahan sudah saatnya untuk penyusunan RDTR dan peraturan zonasi berbasis bidang tanah, sehingga penggunaan/ pemanfaatan tanah lebih akurat dan pasti.

\section{Pernyataan Konflik Kepentingan}

Penulis menyatakan tidak ada konflik kepentingan dalam artikel ini (The authors declare no competing interest).

\section{Referensi}

ATR/BPN, K. (2016). Penyusunan Neraca Penatagunaan Tanah Kecamatan. Jakarta: Direktorat Jenderal Penataan Agraria Kementerian ATR/BPN.

ATR/BPN, K. (2017). Standardisasi Basisdata Spasial Penatagunaan Tanah. Jakarta: Direktorat Jenderal Penataan Agraria Kementerian ATR/BPN.

ATR/BPN, K. (2018). Tata Cara Kerja Penyusunan Neraca Penatagunaan Tanah Kecamatan. Jakarta: Direktorat Jenderal Penataan Agraria Kementerian ATR/BPN.

Bantul, B. K. (2018). Kecamatan Bambanglipuro dalam angka 2018. Bantul: BPS Kabupaten Bantul.
Bantul, K. K. (2017). Penyusunan Neraca Penatagunaan Tanah Kecamatan Bambanglipuro. Bantul: Kantor Pertanahan Kabupaten Bantul.

BPN-RI. (2013). Tata Cara Kerja Penyusunan Neraca Penatagunaan Tanah Kabupaten. Jakarta: Direktorat Penatagunaan Tanah BPN RI.

Prabowo, H. L. (2016). Membangun Basis Data Pertanahan Desa Melalui Inventarisasi Penguasaan, Pemilikan, Penggunaan dan Pemanfaatan Tanah (IP4T) Partisipatif. CGISE (Conference on Geospatial Information Science and Engineering) 2016. Yogyakarta: Teknik Geodesi UGM.

Yogyakarta, B. K. (2018). Kecamatan Mantrijeron dalam Angka 2018. Yogyakarta: BPS Kota Yogyakarta.

Yogyakarta, K. K. (2017). Penyusunan Neraca Penatagunaan Tanah Kecamatan Mantrijeron. Yogyakarta: Kantor Pertanahan Kota Yogyakarta.

Yogyakarta, K. W. (2013). Penyusunan Neraca Penatagunaan Tanah Kota Yogyakarta. Yogyakarta: Bidang Pengaturan dan Penataan Pertanahan Kantor Wilayah BPN DI Yogyakarta.

Yogyakarta, K. W. (2015). Penyusunan Neraca Penatagunaan Tanah Kabupaten Bantul. Yogyakarta: Bidang Penataan Pertanahan Kantor Wilayah BPN DI Yogyakarta. 